Discussion

Papers

Incumbency, Party Identity and Governmental Lead

Evidence for Heterogeneous Incumbency Effects for Germany 
Opinions expressed in this paper are those of the author(s) and do not necessarily reflect views of the institute.

IMPRESSUM

(C) DIW Berlin, 2011

DIW Berlin

German Institute for Economic Research

Mohrenstr. 58

10117 Berlin

Tel. $+49(30) 89789-0$

Fax +49 (30) $89789-200$

http://www.diw.de

ISSN print edition $1433-0210$

ISSN electronic edition 1619-4535

Papers can be downloaded free of charge from the DIW Berlin website:

http://www.diw.de/discussionpapers

Discussion Papers of DIW Berlin are indexed in RePEc and SSRN:

http://ideas.repec.org/s/diw/diwwpp.html

http://www.ssrn.com/link/DIW-Berlin-German-Inst-Econ-Res.html 


\title{
Incumbency, party identity and governmental lead Evidence for heterogeneous incumbency effects for Germany
}

\author{
Florian Ade* $^{*} \quad$ Ronny Freier ${ }^{\dagger} \quad$ Christian Odendahl ${ }^{\ddagger}$
}

December 19, 2011

\begin{abstract}
Do incumbents in an election have an advantage, and if so, are these advantages heterogeneous across parties or government and opposition? We first present a theoretical discussion on the possible heterogeneity of incumbency effects in a pure two-party system. Then, we estimate the incumbency effect for the direct district candidates in German federal and state elections using a regression discontinuity design (RDD). When studying the heterogeneity in these effects, we find that incumbents from both large parties, the center-right CDU and the center-left SPD, have an advantage only if the SPD is in government. This effect is robust and shows even in state elections that are unrelated to federal elections - calling into question the findings of average incumbency effects in the literature. Because this effect is stronger in the East than in the West and only shows post reunification, we hypothesise that the emergence of the socialist party "The Left" may be behind this heterogeneity.
\end{abstract}
Keywords:
incumbency advantage, regression discontinuity
design, federal elections, state elections

JEL classification: H10, H11, H77

Acknowledgments: We would like to thank Charles B. Blankart, Magnus Johannesson, Juanna Jönsson, Per Pettersson-Lidbom, Jesse Rothstein, Björn Tyrefors as well as colleagues at DIW Berlin, Princeton University, Stockholm School of Economics and Stockholm University for helpful suggestions and comments. Furthermore, we would like to thank participants at the the Annual Meeting of the European Public Choice

\footnotetext{
${ }^{*}$ Humboldt University Berlin and DIW Berlin

${ }^{\dagger}$ DIW Berlin

${ }^{\ddagger}$ Stockholm University
} 
Societey, the Workshop on Political Economy at ifo Dresden, and at seminars the DIW Berlin, Humboldt University Berlin, and Stockholm School of Economics. A special thanks goes to Viktor Steiner and Peter Haan who invited us to work at their department for public economics at the DIW Berlin, helped us with contacting the institutions about the necessary data and gave valuable comments and advice. Furthermore, we would like to thank Helke Seitz who provided excellent research assistance with organizing the data. Ronny Freier would like to thank the Hedelius foundation for funding a research visit to Princeton University, Christian Odendahl would like to thank the Hedelius foundation for funding a research visit to the London School of Economics. We are further grateful for editorial support from Adam Lederer. The usual disclaimer applies. 


\section{Introduction}

The electoral advantage of incumbency is perhaps one of the best known and least understood facts of American political life.

Since Abramowitz (1975, p. 668) made this statement, much work has been dedicated to changing this fact. However, there are still new and interesting questions to be investigated: for instance whether there are heterogeneous incumbency effects regarding the party identity or across government and opposition. In this paper, we use data from German federal and state elections to assess this potential heterogeneity in the incumbency effects of district representatives.

We start with some theoretical observations on incumbency effects across parties and government participation in a pure two-party system. The essence is that an interaction term for an incumbent that also belongs to the governing party cannot logically capture a full government participation effect on the incumbency advantage. It can only show the heterogeneity in this effect across parties. The reason is that one interaction effect is the mirror image of the other. If the incumbents of both parties have the same positive effect of being in government, the interaction term will be zero. This also complicates the interpretation of our estimation results because we cannot know which party was driving the effects.

We estimate the incumbency effects for direct candidates of German federal elections between 1976 and 2009 and state elections between 1993 and 2010 using a regression discontinuity design (RDD). We make use of the fact that direct district candidates are elected by a first-past-the-post system and estimate the effect from observations when a candidate just lost or just won an election. This makes the variation in incumbency status arguably as good as random.

We indeed find incumbency effects, but also important heterogeneity between the two main parties, the center-right Christian Democrats (CDU) ${ }^{1}$ and the center-left Social Democrats $(\mathrm{SPD}){ }^{2}$ both parties only benefit from an incumbency effect when the SPD is in government. We explore whether the effect might be driven purely by the SPD because of the increased competition from the left side of the political spectrum. We find three facts in favor of this hypothesis: (1) the effect exists only after reunification, (2) the effect is stronger in the East than in the West of Germany and (3) the vote share of "The Left" ${ }^{3}$ party is directly affected.

\footnotetext{
${ }^{1}$ Christlich Demokratische Union (CDU) and its Bavarian Branch Christlich-Soziale Union (CSU) are referred to as Christian Democrats or CDU for simplicity.

${ }^{2}$ Sozialdemokratische Partei Deutschalnds (SPD)

${ }^{3}$ Die Linke (in English: The Left) was previously called Partei des Demokratischen Sozialismus (PDS). 'The Left' is used for simplicity.
} 
Our estimation of heterogeneous effects shows that average incumbency effects may not be the whole story. In fact, the average of the effect can be misleading and is largely uninformative about potential mechanisms. The observation that a positive incumbency effect for both parties only exists when the SPD in government suggests that many of the usually stories told to explain the effect may not matter at all. Due to the observed heterogeneity, it is unlikely that the effect in Germany is driven by name recognition, media coverage, general pork barrel spending in the districts or helping the constituents in handling bureaucracy ${ }^{4}$ Instead, we believe that our findings lend support to the hypothesis that political competition is one of the main drivers of incumbency effects (Snyder and Hirano (2009)).

Our paper is linked to three incumbency-related strands of literature: to the empirical estimation of incumbency effects in general; to the observation in the literature that incumbency effects seem to be increasing over recent decades; and to papers that try to investigate the heterogeneity of incumbency effects.

A large strand of literature in political science investigates the issue of incumbency empirically $5^{5}$ Lee (2008) uses an RDD to estimate the causal effect of incumbency on subsequent election outcomes. Using data from the US House of Representatives, he finds a sizable incumbency effect of a 45 percentage points higher probability of winning the next election. Following the RDD analysis of Lee (2008), Ferreira and Gyourko (2009) study the effects of incumbency for US mayors. They find an effect of incumbency on the probability of winning of about 32 percentage points.

Empirical studies that use close elections as a source of exogenous variation are not without controversy. Caughey and Sekhon (2011) and Grimmer, Hersh, Feinstein, and Carpenter (2011) show that those candidates in the US House that barely lost and those that barely won are by no means identical on average - an important indication that the design in Lee (2008) might not mimic the empirical gold standard, a randomized experiment. Snyder, Folke, and Hirano (2011) argue in response to the critique that it is true that at the threshold there should be no difference between winners and losers. However, as a practical matter, being near the threshold means that there may be differences simply because cutting a strictly unimodal distribution implies that there will be more probability mass on one side than on the other even when you are reasonably close to the threshold.

\footnotetext{
${ }^{4}$ See for instance Krehbiel and Wright (1983), Cox and Katz (2002), Ansolabehere, Snyder, and Stewart (2000a), Levitt and Wolfram (1997), Cover (1977), Ansolabehere, Snowberg, and Snyder (2006), Cox and Katz (1996), Cain, Ferejohn, and Fiorina (1984) and Bickers and Stein (1996)

${ }^{5}$ See for instance Mayhew (1974), Jacobson (1987), Gelman and King (1990), King and Gelman (1991), Ansolabehere, Snyder, and Stewart (2000b) and Ansolabehere and Snyder (2004).
} 
There is some empirical literature on incumbency effects also for Germany. Hainmueller and Kern (2005, 2008) use an RDD and federal election data to show an average incumbency effect of 1-2 percentage points (in vote share). Our work is closely related to theirs. For local mayors in Germany, Freier (2011) estimates an effect of 38-40 percentage points in the probability of winning. Meanwhile, there is no known empirical investigation of the incumbency effect in German state elections.

The second question in the literature, which our contribution is connected to, is why the incumbency advantage seems to be increasing over recent decades ${ }^{6}$ In an early paper on the issue, Mayhew (1974, p. 313) hypothesizes:

Voters dissatisfied with party cues could be reaching for any other cues that are available in deciding how to vote. The incumbency cue is readily at hand.

However, Ansolabehere, Hirano, Snyder, and Ueda (2001) and Krehbiel and Wright (1983) reject the hypothesis that persons have replaced parties in this respect. Our results also indicate that the incumbency advantage has increased in Germany since reunification in 1991. Since party loyality were less strong in the East, this may be one aspect, but we leave this investigation to future research.

Finally, our paper is related to the literature that tries to identify heterogeneity in incumbency effects. For example, Snyder and Hirano (2009) investigate the heterogeneity of incumbency advantages regarding competitiveness and budget size and find sizeable differences. To the best of our knowledge, the heterogeneity that we investigate - government participation - is not studied in any existing rigorous empirical research design.

One final introductory point: some studies use the vote share, some the probability of winning as an outcome variable and naturally are they closely related. Since probability of winning works better when parties decide not to (re-)run, it has become the more standard outcome variable. However, we show that during large political swings the probability of winning may end up at its boundaries zero and one, which hides any potential incumbency effect.7 Again, by disregarding this important feature in the probability of winning, average incumbency effects in this measure are potentially very misleading. For that reason, we prefer the vote share as our measure of outcome 8

\footnotetext{
${ }^{6}$ See Cox and Katz (2002) for an example and Jacobson (1987) for a discussion of what "increase" actually means and, more importantly, does not mean.

${ }^{7}$ This issue is related to but different from the one identified in Jacobson (1987). Our concern is that the choice of variables may hide an empirical result.

${ }^{8}$ Note that in Germany the two large parties, CDU and SPD run in every single election that we observe. Thus, we do not have to be concerned about strategic entry or exit into the district races.
} 
The remainder of the paper is organized as follows. Section 2 discusses the logical necessities in estimating heterogeneous incumbency effects in a pure two-party system, and the institutional background for German elections. In section 3 we present our empirical strategy, section 4 shortly introduces the data we use and section 5 presents and discusses the results, the interpretation and some validity and robustness checks. Section 6 concludes the analysis.

\section{Theoretical and Institutional Background}

\subsection{Theoretical considerations}

We begin with some logical observations on incumbency effects and the potential to identify heterogeneity by government participation. To fix ideas, we assume a two-party system and introduce the following notation. There are two parties $j=C, S$, and the outcome variable is the vote share in the next election for the respective parties: $Y^{C}$ and $Y^{S}$. Then:

$$
Y^{C}=\alpha^{C}+\beta^{C} g^{C}+\gamma^{C} d^{C}+\delta^{C}\left(g^{C} \cdot d^{C}\right)
$$

and

$$
Y^{S}=\alpha^{S}+\beta^{S} g^{S}+\gamma^{S} d^{S}+\delta^{S}\left(g^{S} \cdot d^{S}\right)
$$

where $g^{j}$ is the dummy for government participation of party $j$ and $d^{j}$ is a dummy equal to one if the incumbent is from party $j$. At first glance, one could imagine bringing one of the two equations to the data (using different districts and different time periods) and estimate the parameters $\delta^{j}$. Would, e.g., $\delta^{C}$ give us an indication on the heterogeneity in the incumbency advantage when party $C$ is in government? The answer is no. The analysis is complicated by the interaction of parties.

To clearify this, note that, in a two party system, there are three equalities that we know hold:

$$
\begin{gathered}
g^{C}=1-g^{S} \\
d^{C}=1-d^{S} \\
Y^{C}=1-Y^{S}
\end{gathered}
$$


If we insert the above equalities into the equation 1 and rearrange, the relationship between the parameters for the two parties is as follows:

$$
Y^{S}=\underbrace{\left[1-\alpha^{C}-\beta^{C}-\gamma^{C}-\delta^{C}\right]}_{=\alpha^{S}}+\underbrace{\left(\beta^{C}+\delta^{C}\right)}_{=\beta^{S}} g^{S}+\underbrace{\left(\gamma^{C}+\delta^{C}\right)}_{=\gamma^{S}} d^{S}+\underbrace{\left(-\delta^{C}\right)}_{=\delta^{S}}\left(g^{S} \cdot d^{S}\right)
$$

There are two key observations to extract. First, and most importantly, the relationship between parameters on the interaction term is fixed to $\delta^{C}=-\delta^{S}$. Somewhat surprisingly, this implies that the parameters $\delta^{C}, \delta^{S}$ cannot capture an effect that incumbents from either party can receive (we cannot have $\delta^{j}>0$ for both parties). Thus, an empirical specification that uses models like the ones presented here will not identify a universal government bonus for incumbents.

The intuition for this effect is as follows. Say, both parties are equally able to push their district incumbents only when they are in government. Say further, party $C$ is in government and can make it such that the party receives an additional $5 \%$ in votes in the next election in all districts with party $C$ incumbents (because resources by the government were channelled to the district or the incumbents could receive more media attention). Via this mechanism we now observe an incumbency advantage for party $C$ incumbents.

Now assume that party $S$ is in government and can engage in the same behaviour. Districts in which party $S$ is incumbent now receive an additional $5 \%$. This is the same as saying that party $S$ will do worse (relatively) in districts with party $C$ incumbents. Crucially this implies that we would observe that party $C$ incumbents also have an incumbency advantage. Despite the fact that the mechanism is driven by the access to government of the incumbents of party $S$, we observe that incumbents from both parties have an incumbency advantage. If both have the same government bonus, $\delta^{S}=\delta^{C}$ will be zero. If a universal government bonus exists and contributes to the incumbency advantage it will be indistinguishable from other mechanisms.

Say, we find $\delta^{S}$ and $\delta^{C}$ to be significiant $\left(\delta^{j} \neq 0\right)$. This neccessarily implies that there is heterogeneity in how both parties can capitalize on a government bonus. It is only if, e.g., one party can use the government bonus and the other cannot, that we can empirically observe $\delta^{S}$ and $\delta^{C}$ to matter. Note, that similar to above, we can still not say, which of the two parties is actually driving the results.

The second key observation is that the parameters $\delta^{j}$ and $\gamma^{j}$ interact in $\gamma^{S}=\gamma^{C}+\delta^{C}$. Assume that $\gamma^{C}$ is positive and $\delta^{C}$ is negative and both have the same size in absolute values. That implies that $\gamma^{S}$ is zero and $\delta^{S}$ is positive. What at first looks as if party $C$ is 
punished when in government (while party $S$ gains) can also be interpreted as showing that both have an incumbency effect when party $S$ is in government: $\gamma^{C}$ for party $C$ and $\gamma^{S}$ plus $\delta^{S}$ for party $S$. This is the way we interpret our results below. Stated differently, when we hold the governing party constant, the incumbency effects of one party is the mirror image of the effect for the other. For more clarity, we supply a graphical interpretation of these considerations in the appendix.

Turning from the simple example to the actual data, we should note that the German system includes more than two parties. However, there are two major parties (CDU and SPD) that participate in every district during federal elections. Almost all directly elected candidates come from one of the two major parties. Hence, we expect the results to be a noisy representations of the above logical observations.9

\subsection{Electoral system}

The German electoral system at the federal and state level is a mixed-member proportional system. The intention of such a system is to have proportional representation in parliament without sacrificing local representation and accountability of the legislators. Therefore, voters make two distinct choices on election day. First, they cast their ballot for the representative of their district (hereafter direct candidate) in a first-past-the-post system. Second, they elect the party for the proportional representation in parliament (hereafter second ballot).

There are twice as many seats in the federal parliament (Bundestag) as there are electoral districts. The second ballot determines the number of seats that a party can fill in total, and it is calculated with the Sainte-Lague algorithm. $\sqrt{10}$ Direct candidates always get their seat; the remaining seats are filled through the party lists. If there are no remaining seats, that can happen if, a party has more winning direct candidates than there are seats for it, the party will get one more seat in the federal parliament, a so called overhang seat (Überhangmandat).11

${ }^{9}$ Cox and Katz $(2002)$ analyze the incumbency advantages for Republicans and Democrats separately and find interpretable differences. However, in a pure two-party system one should be the mirror image of the other. Their results and interpretation is therefore at odds with our theoretical considerations.

${ }^{10}$ This algorithm divides the total number of votes by the total number of seats. The resulting quotient is the "price" for each seat. In a next step, the number of votes that each party receives (their "budget") is divided by this quotient or "price" to get the exact number of seat that this party should receive with perfect proportionality. Using standard rounding, these exact numbers are then turned into integers.

${ }^{11}$ The exact calculation in the federal election is complex, as the algoritm applies separately to each state. The resulting overhang seats in the federal election are not compensated for, which implies that proportionality can be violated. In 2009, the federal election resulted in 24 overhang seats (out of a total of 622 seats), all for the CDU (or CSU in Bavaria), whereas in 2005 there were 7 for the CDU and 9 for the 


\section{Empirical Strategy}

The empirical challenge for estimating incumbency effects is that incumbency is not exogenous: comparing the vote share of those districts with CDU incumbents to those with SPD incumbents will tell us nothing causal about the effect of incumbency. We therefore rely on a regression discontinuity design (RDD) to isolate exogenous variation in the incumbency status 12 The model that we use for our estimation is

$$
y_{i, t+1}=\alpha+\beta_{t}+\gamma d_{i, t}+\delta d_{i, t} g_{t}+h\left(v_{i, t}, d_{i, t}, g_{t} ; \theta\right)+\phi_{s}+\epsilon_{i, t}
$$

We run a separate regression for both parties, CDU and SPD, but leave out the superscript $p$ for better readability. For the same reason, we also leave out the superscript $s$ denoting the state that a district belongs to. The outcome variable $y_{i, t+1}$ is the vote share of that party's direct candidate in the next election $t+1$ in district $i$. In later specifications we also use the probability of winning or the vote share of the second ballot in the next election as an outcome variable.

The coefficients of interest are $\gamma$ and $\delta$, where $d_{i, t}$ is the incumbency or treatment dummy and $g_{t}$ denotes whether the party in question was in government or not. The $\beta_{t}$ replaces the stand-alone $g_{t}$ term as these election fixed effects $\beta_{t}$ are collinear with the government dummy.

The function $h(\cdot)$ is the control function of the margin of victory, $v_{i, t}$; that is, the difference in vote share between the candidate in question and the best opponent. This margin of victory can be positive or negative, depending on whether the candidate of that party won or lost. A margin of victory close to zero implies a very close race and the relationship between $d_{i, t}$ and $v_{i, t}$ is as follows:

$$
d_{i, t}=1\left[v_{i, t}>0\right]
$$

The function $h(\cdot)$ is fully interacted with the incumbency and government dummies. While interacting the control function with the treatment dummy $\left(d_{i, t}\right)$ is common practice, the interaction with the government dummy $g_{t}$ serves an important purpose, too. We allow the effect of the vote share in $t$ to have a different impact on the vote share in $t+1$ depending

SPD. In state elections, these overhang seats are usually compensated for by giving other parties additional seats, too. The details regarding these so called leveling seats (Ausgleichsmandat) vary.

${ }^{12}$ Others use a similar design using close elections in order to estimate causal effects of political outcomes. Lee, Moretti, and Butler (2004) and Pettersson-Lidbom (2008) are among the first, Hainmueller and Kern (2008), Ade and Freier (2011), Freier (2011), Freier and Odendahl (2011) are examples in the context of Germany. See Imbens and Lemieux (2008) for a more general treatment of RDDs. 
on whether the party in question is in government or not. This mimics the approach of estimtating the incumbency effect in separate samples for being in government or not. Finally, we include state fixed effects $\phi_{s} \cdot{ }^{13}$

After this short description of our empirical approach, we discuss the RDD approach and its assumptions before turning to the issue of whether we can causally interpret the interaction term. In general, RDDs have a forcing variable $v$ that may or may not be correlated with unobserved variables that affect the outcome $y$. In our case, the margin of victory is the forcing variable $v$ and is correlated with a general preference for one or the other party. Our outcome is vote shares in the next election, which is clearly related to both preferences and the margin of victory. However, there is a discontinuous jump in the party identity of the winner. So even though $v$ is related to $y$, it is so continuously, which implies that the jump in our treatment variable is exogenous.

Our design is therefore based on the assumption that the expectations of the potential outcomes $y_{0}$ and $y_{1}$ in a Rubin Causal Model are continuous in the forcing variable $v[14$ That is, the vote share of the CDU in the next election should be continuously related to the current margin of victory $v$ of the CDU candidate in both worlds: whether the CDU candidate wins or loses.

For example, one concern is that parties could be able to sort around either side of the threshold $v=0$. That is, if there is some unobservable factor that makes CDU candidates the winner in some close races but not others, the design would be invalid because potential outcomes would not be continuous in $v$.

It is impossible to test this key assumption directly since we cannot observe the outcomes in both worlds, when the CDU candidate wins and loses. However, we can offer auxiliary methods to assess whether it is plausibly satisfied.

Another concern is that parties strategically place candidates in contested districts. There are two arguments in favor of our approach. First, both parties would strategically place candidates. Second, the direct candidates are usually of a local breed, which limits the scope for the party to strategically place a specific candidates. What is more, this would not necessarily invalidate our design: if it is still random whether they lose or win if the race is close, our results remain internally valid. External validity is a different matter, but the two arguments in favor of our approach mitigate a potential problem here.

\footnotetext{
${ }^{13}$ There are 16 states, including three city-states, in Germany, with a total of between 250 and 325 districts. For example, the city-state of Berlin has 12 districts.

${ }^{14}$ See Imbens and Lemieux (2008) for details.
} 
The inclusion of a control function is essential, unless we are very close to the threshold. A correctly specified control function will capture any correlation of $d_{i, t}$ with the error term that might be of concern. In our estimations we use a sample limited to observations within a $2 \%$ margin of victory without a control function, the $5 \%$ margin sample with a linear control function, and the whole sample with a 4 th order polynominal control function.

The effect that we are estimating is of course local in nature: we are only using close election outcomes for identification. However, because of the first-past-the-post system the vote share of winners ranges from around $30 \%$ to $47 \%$ because the smaller parties typically nominate a direct candidate as well.

It is important to note that we are estimating the incumbency of parties and not of specific candidates. While it might at first appear to be more intuitive to study the incumbency effects of specific candidates that run for consecutive elections, such an analysis requires significantly more data and econometric modeling 15 The major issue complicating the analysis is the endogenous choice of the candidates to exit the race. A candidate that considers it unlikely to win next time will choose to opt out, while a sure winner may be more likely to stay in the race. This would bias our results because we can only look at those that stayed in the race. Incumbency (or (re-)running) would then be related to the expected vote in future elections ${ }^{16}$

By focusing on party incumbency we eliminate this problem. Our incumbency measure, also used by Lee (2008) and Hainmueller and Kern (2008), includes the personal incumbency effect without bias as well as potential spillovers to a new candidate from the same party.

We now turn to the causal interpretation of the interaction term. Our RDD setting allows us to estimate a causal effect of incumbency in each of the four possible samples separately: CDU plus CDU in government, CDU plus SPD in government, SPD plus CDU in government and SPD plus SPD in government. Under the assumptions discussed above, each of these effects compares bare CDU winners to bare CDU losers (and likewise for the SPD). When we interpret the interaction effect causally, we in effect compare the effects in these four different samples.

This comparison is problematic insofar as there may be other aspects affecting the incumbency effect and that are correlated with the party in government. When we offer interpretations for heterogeneous incumbency effects, we always do so with the caveat in

\footnotetext{
${ }^{15}$ See Gelman and King (1990) for a full discussion of the personal incumbency advantage.

${ }^{16}$ Cox and Katz (2002) discuss this issue in detail, while Ansolabehere and Snyder (2004) show that it is less of a problem in US elections.
} 
mind that government participation may not be the whole story. However, one of our robustness test - estimating the same interaction effect in 13 election periods between 1994 and 2010 from eight different German state elections - shows that the effect is similar. This increases our confidence that government participation may be the decisive factor in the comparison. We return to this issue in section 5.3 .

\section{Data}

We use official election data for federal and state elections. In table 1 we summarize the data for the federal elections. Starting with the election in 1976, there are nine government terms, with the last election in 2009. Since the last government term saw a so called "grand coalition" of the center-right CDU and the center left SPD, we only include the last period in robustness tests. Three terms ended before the official four years were over: in 1983 a government change led to new elections, in 1990 the reunification required a shorter duration and in 2005 chancellor Schröder called for a federal election after his unpopular Agenda 2010 reforms led to landslide victories for the opposition in several state elections.

One concern with the data is redistricting of the electoral districts, in particular before the 2002 election. ${ }^{17}$ We exclude observations of districts that had seen substantial changes in the structure of the voting population. The number of observations reported in table 1 may therefore deviate from the absolute number of districts. Column 3 of table 1 contains the leading party in the government coalition. 18 Columns 4 and 5 show the number of direct seats that both parties have won. The final two columns show, for the CDU only, how many of the races were close: 199 using a $2 \%$ margin and 514 using a $5 \%$ margin. Since the leading candidates in almost all districts are from CDU or SPD, this also gives an indication of how many were close for the SPD. Only in recent years has the SPD seen a few more tight races in districts where they had competition from third parties.

During our robustness tests, we also estimate incumbency effects and government participation at the state level. The descriptive statistics for these are given in table 4 in the appendix.

\footnotetext{
${ }^{17}$ For the 2002 election, the number of districts was reduced to 299 from 328 . We analyzed this reform and found that 238 districts remained structurally unchanged. To make sure that the inclusion of these observations does not drive our results, we exclude this year from robustness tests but results remain unchanged.

${ }^{18}$ The first and the last government term is special in this respect. In the 1980-83 period, the government changed after three years from a SPD-FDP coalition to a CDU-FDP coalition. The latter coalition, however, only governed for four months before an early election took place, so we coded the period as "SPD". In the 2005-09 period, Germany had a so called "grand coalition" that consists of the two large parties CDU and SPD. This period is coded as both CDU and SPD.
} 
Table 1: Descriptives - federal elections

\begin{tabular}{|c|c|c|c|c|c|c|}
\hline \multirow[t]{2}{*}{ Period } & \multirow[t]{2}{*}{ Obs. } & \multirow{2}{*}{$\begin{array}{c}\text { Head of } \\
\text { Government }\end{array}$} & \multicolumn{2}{|c|}{ Seats won } & \multicolumn{2}{|c|}{ Tight elections (CDU) } \\
\hline & & & $\mathrm{CDU}$ & $\mathrm{SPD}$ & $2 \%$ margin & $5 \%$ margin \\
\hline '76-'80 & 161 & SPD & 98 & 63 & 18 & 41 \\
\hline '80-'83 & 248 & $\mathrm{SPD}^{a}$ & 121 & 127 & 20 & 49 \\
\hline '83-'87 & 248 & $\mathrm{CDU}$ & 180 & 68 & 22 & 57 \\
\hline '87-'90 & 248 & CDU & 169 & 79 & 21 & 51 \\
\hline '90-'94 & 322 & $\mathrm{CDU}$ & 232 & 89 & 24 & 60 \\
\hline '94-'98 & 325 & $\mathrm{CDU}$ & 221 & 100 & 25 & 71 \\
\hline '98-'02 & 238 & SPD & 97 & 140 & 20 & 60 \\
\hline '02-'05 & 296 & SPD & 125 & 168 & 22 & 61 \\
\hline \multirow[t]{2}{*}{ '05-'09 } & 279 & $\mathrm{CDU}^{b}$ & 138 & 137 & 27 & 64 \\
\hline & 2365 & & 1381 & 971 & 199 & 514 \\
\hline
\end{tabular}

$a$ After the first two years of the four year term the coalition partner of the SPD, the FDP, decided to cooperate with the CDU and elected a CDU chancellor. In order to morally legitimize the new government called for early election in 1983. Overall the the $\mathrm{CDU}$ led government was in power for only four months before the premature election. Hence the SPD headed the government for most of the period and we coded the period as SPD governed.

$b$ Coalition government of CDU and SPD, led by the CDU. Notes: Source: Own

calculations based on the data provided by the state offices for statistical services.

\section{Results}

\subsection{Main results}

The results of our main estimation are presented in table 2. The upper panel shows the results for the estimation using only the center-right party (CDU), the lower panel the results using the center-left party (SPD). We estimate three different specifications that we repeat for each of the different cases. The first only uses data from observations within a 2 percentage points margin around the threshold, the second specification uses data with a five percentage point margin and also includes a linear control function, and the last uses the full sample while making use of a fourth order control function. Without a government interaction term, the effects for both CDU and SPD should have the same size and sign in a pure two-party system, as outlined in section 2. The first three columns of table 2 show that this holds true even in the German system that is not a pure two-party system. The first line shows the estimates for the CDU in all periods that we consider, that is, 1976-2009. They compare well to the first line in the lower panel for the SPD. The bottom estimates of both panels show the average incumbency effect for the period 1990-2005. Our estimates are in the same ballpark as those of Hainmueller and Kern (2005).

Turning to the heterogeneity in the effects in columns 4-6, we find that the CDU and the SPD have a positive incumbency effect in periods when the SPD was in government: in 
column 4, the CDU candidate gains $2.9 \%$ points in the subsequent election after when a CDU candidate barely won the past direct candidate election, but is not in government, whereas the SPD gains 3.5\% points (treatment estimate plus interaction term). These effects compare well to alternative specifications in columns 5 and 6 . When the CDU is in government, the effects for both parties are insignificant.

The lower part of both panels show the same effects for the later period 1990-2005, that is, after reunification. The effects are noticeably larger, albeit not significantly so. Comparing the effects also to the subperiod from 1976-1990, we find that the overall effect is entirely driven by the later subperiod. In fact, for the early period, even the average incumbency effect cannot be consistently found.19 We return to those before and after reunification differences in the discussion of the results in section 5.2 .

We can also inspect these effects graphically. Figure 5.1 shows the incumbency effect from the perspective of the CDU. When the CDU is not in government, there is a sizable jump of roughly 3 percentage points in the vote share during the next election. This compares well to the stylized figure 4 in the appendix. Figure 5.1 contains the same effect when the $\mathrm{CDU}$ is in government. As the estimation results suggest, there is no incumbency effect.

So far, we consider the vote share as our outcome variable. How these gains in vote share translate into a probability of winning is what we turn to next. Table 3 is structured in the same way as table 2. In columns 1-3, we see an average incumbency effect of roughly 22 percentage points in the probability of winning, which again is in the same ballpark as those in Hainmueller and Kern (2005). Columns 4-6 show that the incumbency effect on the probability of winning is only present if the SPD is in government: $43.8 \%$ points for the CDU candidate, and $34.7 \%$ points for the SPD candidate. All effects are stable across different specifications. ${ }^{20}$

However, there is a problem with using the probability of winning as an outcome variable: it is bounded at zero and one. While this is theoretically true for the vote share as well, it is not of practical importance there. For the probability of winning on other hand, this can pose a serious problem for the estimation. Figure 5.1 displays the incumbency effect on the probability of winning for a specific election pair graphically. The left hand side shows the probability of winning in 2009 for SPD incumbents from 2005. The probability of winning would yield an incumbency effect of zero, so what happened?

\footnotetext{
${ }^{19}$ That is not to say that an average incumbency effect does not exist. However, it is noticable that we cannot pick it up in the data consistently before but can after reunification.

${ }^{20}$ For the period before 1990, the average incumbency effect using the probability of winning as an outcome is roughly the same (not shown). However, the interaction term is insignificant.
} 
Figure 1: Incumbency effect for the CDU - CDU not in government

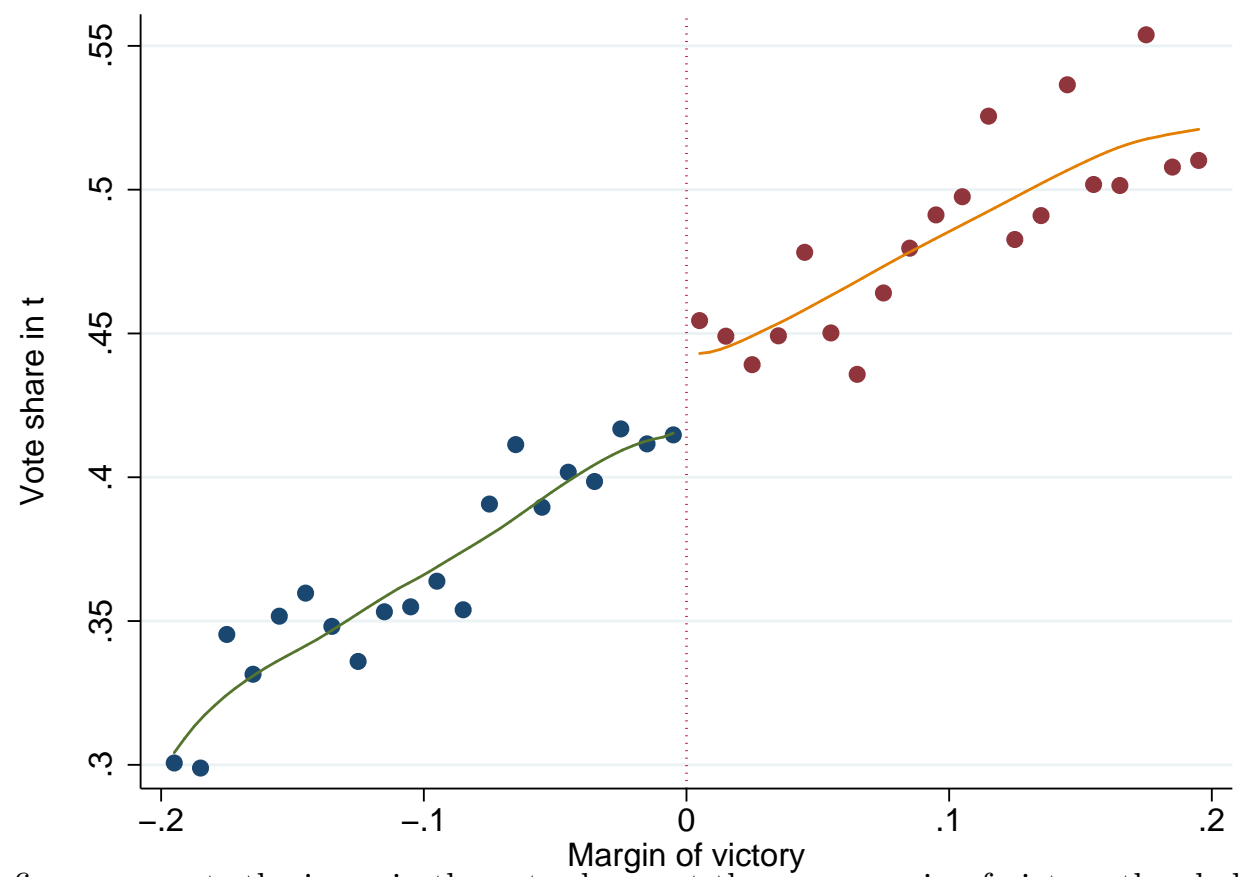

Notes: This figure presents the jump in the vote shares at the zero margin of victory threshold. The data is grouped in bins of $1 \%$ in the margin of victory. The line is based on a local kernel estimation using Epanechnikov weights. Source: Own calculations.

The explanation is that there was a large shift in the political landscape in 2009 (the outcome variable for these graphs is from 2009), when the SPD lost many seats to the CDU. At the margin, that means that nobody in the SPD that won with up to a $2 \%$ points margin in 2005 reclaimed their seats. The mirror image of this is that everyone from the CDU with up to $-2 \%$ points margin of victory in the 2005 election, won a seat. The essence of this is that large political swings can bring the probability of winning to its lower and upper bounds.

This can potentially be problematic for any study that uses the probability of winning as the outcome variable. If the probability of winning is at its boundaries at times of large political swings and not at others, the interpretation of an average incumbency effect in this measure is misspecified. As pointed out in figure 5.1, there can be times in which an incumbency advantage may exist (in vote share, see right panel), however, the probability of winning cannot pick it up. This is why the vote share is our preferred outcome measure.

\subsection{Discussion}

The theoretical observations in section 2 above show that the interaction term can only capture heterogeneity, not a full government effect on incumbency. Moreover, we saw that 
Figure 2: Incumbency effect for the CDU - CDU in government

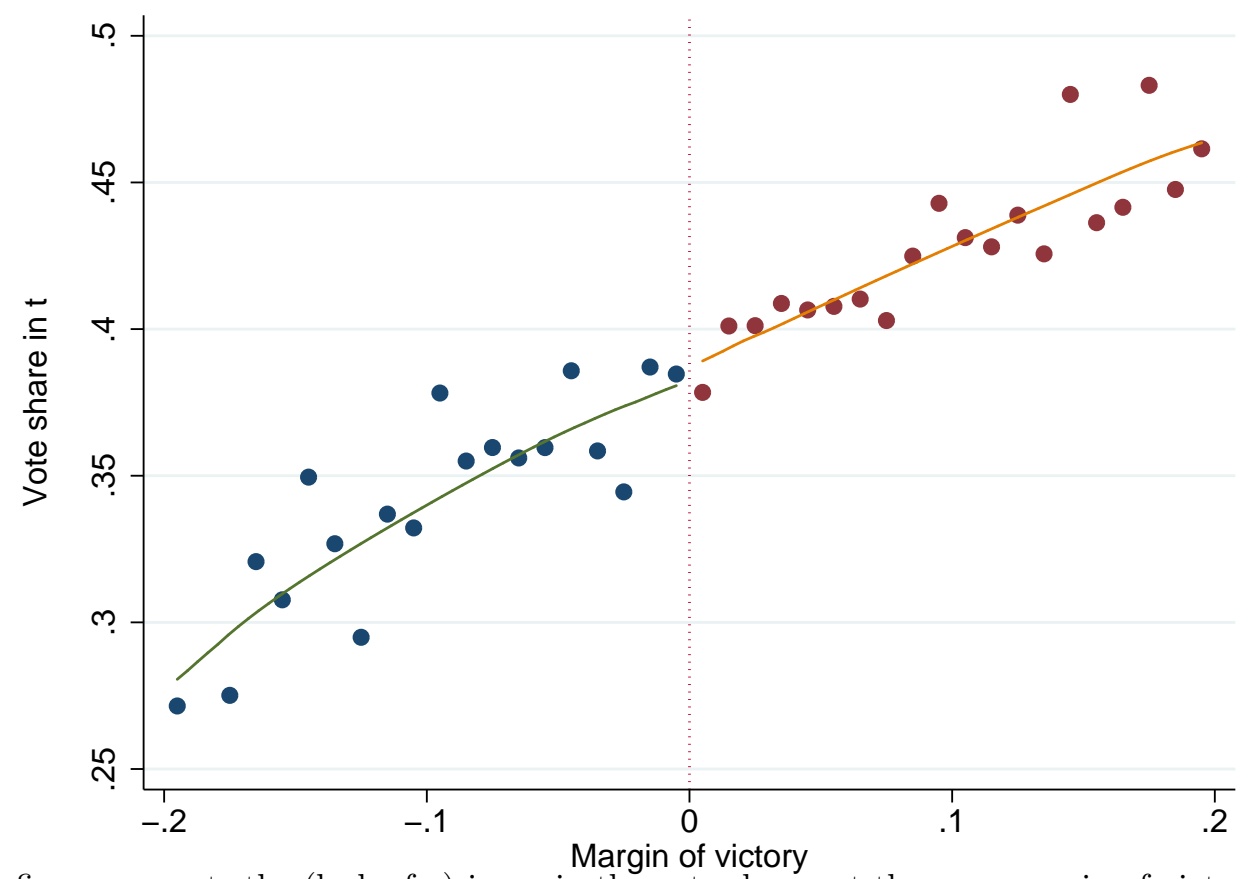

Notes: This figure presents the (lack of a) jump in the vote shares at the zero margin of victory threshold. The data is grouped in bins of $1 \%$ in the margin of victory. The line is based on a local kernel estimation using Epanechnikov weights. Source: Own calculations.

both parties have an incumbency effect when the SPD is in government, but none when the $\mathrm{CDU}$ is in government. Whether the CDU or the SPD is driving the former effect - one must be roughly the mirror image of the other - and what might be the underlying reason for the heterogeneity, is the question we explore next.

Our hypothesis is that the social democrats (SPD) are driving the effect and that the increased competition by a far-left party that emerged after reunification is the reason behind the heterogeneity. After the fall of the wall in 1989, the SPD soon faced a serious competitor from the left, the post-communist party The Left (Die Linke/PDS). We believe that in this setting SPD-district representatives are only successfully in district races against CDU and The Left if they hold the incumbent position and have the backing of the government. It is only then that these representatives may successfully promote the district's interests in actual decision making while they were weak and easy to attack in all three other cases ${ }^{21}$

There are three key arguments supporting our hypothesis. First, the heterogeneous incum-

\footnotetext{
${ }^{21}$ The literature also suggests that political competition may well be the reason for an incumbency advantage. Snyder and Hirano (2009) find that the incumbency effect is larger in competitive districts. Stein and Bickers (1997) suggest that incumbents in competitive districts may use the resources of office to a larger extent, which is in part confirmed in other contexts, for instance for competitively elected judges in Gordon and Huber (2007).
} 
Figure 3: Probability of winning vs. vote share as an outcome variable, SPD in 2009
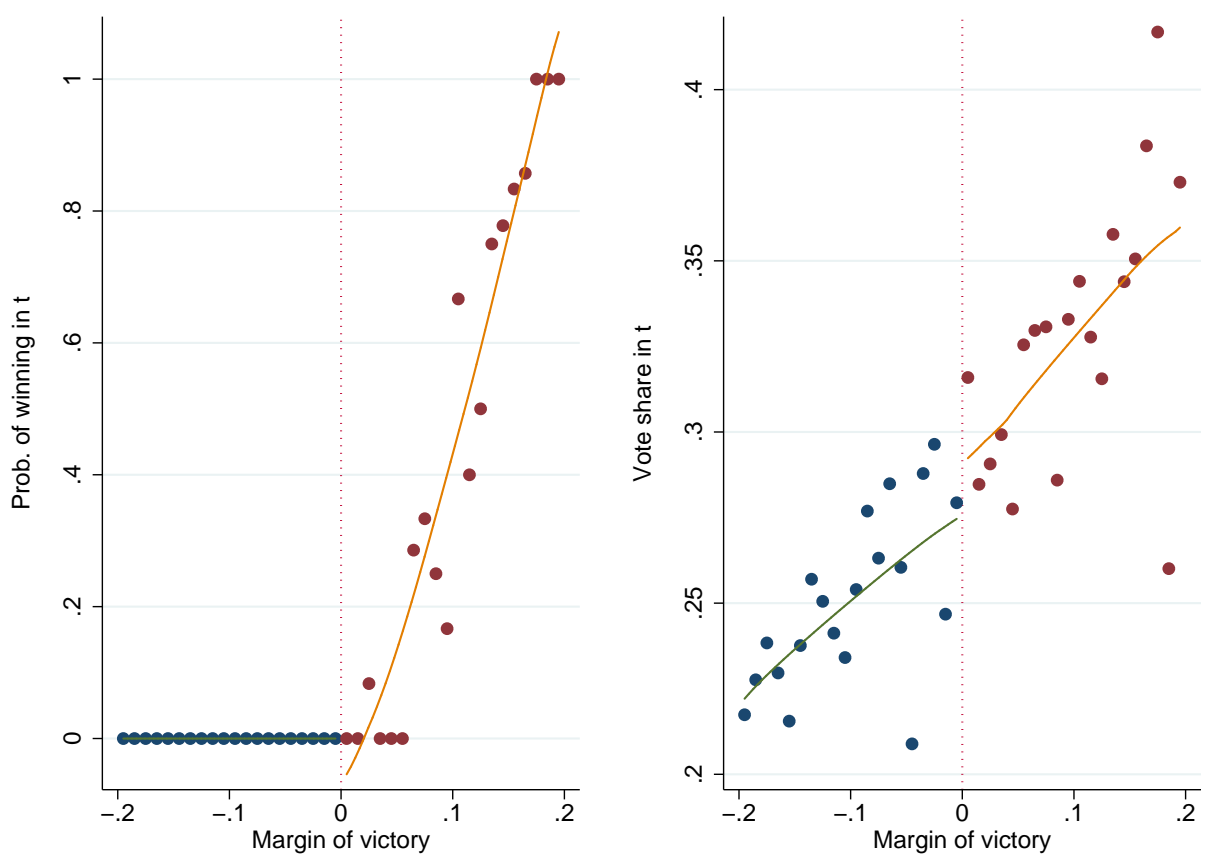

Notes: The left part displays the probability of winning by margin of victory for SPD incumbents in 2005, using the 2009 election results as outcome variables, the right hand part the vote share. Source: Own calculations.

bency effect is really only observable after reunification (as argued before), second, it is stronger in East Germany and third, we can show that district incumbency for the SPD has a direct negative effect on the votes share of The Left.

Regarding the first argument, we have already highlighted the differential effects for the period before and after 1990 in tables 2 and 3.

The second argument that the effects are stronger in the east is shown by table 5 in the appendix. The effects in the East are between 2 and 5 times as high, albeit not as robust across different specifications, while the effects in the West are still significant and reasonably robust. What is special about Eastern Germany is the vote share of the socialist party The Left. Figure A.2 in the appendix shows that the median in the East was between $10 \%$ and 30\%, while in the Western districts it was below 5\% until 2009 when they reached around $7 \%$.

The third point, that an SPD incumbent had a negative impact on the vote share of The Left, is presented in table 6 in the appendix. We read this table from the perspective of an SPD incumbent: treatment $d$ is defined as winning a seat for the center-left SPD, and the government dummy $g$ indicates whether the SPD was in government. The outcome, 
however, is the direct candidate and second ballot vote share of The Left, not of the SPD. The results show that the SPD incumbency effects when the SPD is in government might have been partly at the expense of the left party, even though the effect is not stable across all specifications.

Summing up, there is considerable evidence for our hypothesis that the SPD, under increasing competition, may have scaled up its efforts in districts with winning SPD candidates. Thus, increased competition from the far left may drive the heterogenous incumbency effect: Not only are the effects bigger in the East, where The Left has its strongholds, and higher after 1990, but also there is a negative effect of SPD incumbents on The Left voteshare. A further indication that these observations are not casual is that we find the same heterogenous effects for state elections (see table 8 in the appendix).

Although we believe that there is support for our hypothesis we emphasize that all those arguments can only give an indication. The RDD analysis in subgroups (east-west, before and after 1990) does not explain what determines the differences between these groups but only shows that they exist. In principle, one could argue that other than the above presented mechanism could cause the different results for the subsamples. To rule out some alternative explanations, we investigated whether candidate characteristics differ by whether SPD or CDU is in government. For that, we coded the biographies of all close winners in our sample 22 We ask whether either one of the following four alternative hypotheses could play a role in the observed differences: 1.) Increase in the share of women in parliament, 2.) changes on ties of candidates to their local constituency, 3.) differences of qualification level of the candidates and 4.) tenure in the parliament and party. The results are presented in table 9 in the appendix.

First, we look at the share of women by party and governmental lead. Voters might be biased towards women as politicians, and women could receive less of an incumbency advantage as a result. Also, there have been changes in the structure of female participation in parliament during the period of observation. However, while it is true that the SPD has a higher share of women among the winners of close races, there is no difference between times in which the CDU or SPD had the governmental lead. We conclude that the observed heterogeneity in the incumbency effects cannot be explained by the number of female candidates in the

\footnotetext{
${ }^{22}$ We took the biographical information from the periodical publication "Kürschner's Jahrbuch" in which all members of parliament of a given period are briefly introduced. We did this for every district that was decided within a margin of victory of 2 percentage points, which we believe is a close margin. Unfortunately, we only observe these characteristics for the winner of close races, and we cannot consistently compare these characteristics also for the losers. This implies, that we cannot directly introduce those variables in the RDD analysis.
} 
races 23

Moreover, we coded whether a candidate was born in the district as a proxy for the local ties of a candidate. Although the difference in shares is not negligble (particularly for the SPD), those differences are not significant.

We also investigate two measures of candidate quality, the share of university graduates and the share of candidates that hold important positions in the party or the government 24 There is no indication that candidates of SPD and CDU were different depending on who was in charge of the government.

Lastly, we coded the seniority of the candidates both within the parliament and in the party. We have information on how many periods and years a candidate has served in the parliament (at the time of winning the close race) and about the years of membership with the party. Also, here we do not observe any differences.

We also repeated this analysis for the later period (1990-2005) only for which we find strong heterogeneity effects (not reported). Also in this period, we do not observe significant differences of candidate characteristics by governmental lead ${ }^{25}$

Overall, the analysis of the candidate characteristics does not hint at an alternative explanation as to why we observe the heterogeneous incumbency effects. While this does not directly imply that our preferred hypothesis is indeed correct, it makes it more likely that this is the case.

Moving from the specifics of our interpretation to broader political economics questions, our results show that positive and significant estimates of an incumbency effect may not show what they seem to show. In our case, the average incumbency effect for both parties may lead readers to believe that both have an incumbency effect. Yet the effect differs by party and government participation as we have seen. The theoretical explanations as to why these effects exist (e.g. media coverage, name recognition) may therefore be very different once we consider heterogeneity.

\footnotetext{
${ }^{23}$ Note, that the share of women indeed increased sharply after 1990 in the SPD. However, within the subperiod from 1990-2005 there is no significant differences in the number of women among close winners by governmental lead.

${ }^{24}$ We coded a candidate to be in an important position if she was holding a position in the cabinet, as a undersecretary in a ministry, was active in the board of the party, heading a parliamenary committee or was the spokesperson of the party.

${ }^{25}$ Among all the characteristics we observe one significant difference (only at 10 percent level). Results are available from the authors upon request.
} 


\subsection{Robustness and Validity}

In this final subsection, we offer some robustness and validity checks for our main results. A first robustness check is whether these results hold for state elections as well - a government level in Germany not been covered so far by other empirical studies on the subject. State elections work in a similar way as federal election with the added complication that if there are overhang seats, the other parties are compensated in some way such that the proportionality is roughly preserved. This in turn implies that direct candidates change the final result of the election to a lesser extent. Moreover, the direct candidates - especially in the Eastern states - do come from parties other than CDU and SPD, moving us further away from a pure two party system.

Table 8 in the appendix provide the results for the state elections that confirm our analysis on the federal level. For the center-right party (CDU), the effects are very robust and slightly larger than the federal effects. ${ }^{26}$ For the center-left party (SPD), the effects are not as stable, which indicates that on the state level the party system is more diverse even for the direct candidates. However, they still indicate that being in government is in relative terms - beneficial for SPD incumbents: when the SPD is not in government, the incumbency effect is an insignificant $-4.5 \%$ points in column (6); when the SPD is in government, the effect is $3.9 \%$ and insignificant as well. However, the difference between the two is significant.

The results for the second ballot of the election, can also serve as a further robustness test. In table 7 in the appendix, we find that a spillover effect of incumbency (incumbency externality effect) towards the second ballot exists and go in the same direction as our main results. The effects for the CDU are very robust: the average incumbency effect is slightly positive and significant but when disaggregated by government participation, the incumbency effect is only positive when the opposition is in government. For the SPD, the effects are less strong and robust, but have the same sign as those for the direct candidates 27 The fact that the SPD results are less clear in the second vote is somewhat puzzling. Unfortunately, we did not find a fully consistent story in the data, that could help us to understand this observation.

In two further robustness checks, we exclude the 1998-2002 period and include the 20052009 period respectively. There are two concerns with the 1998 election and the vote share

\footnotetext{
${ }^{26}$ Note that the state elections come from the post-reunification period only. Therefore, the correct comparison is the lower panel of the federal table.

${ }^{27}$ For the second ballot, Germany clearly has a multi-party system, which brings us even further away from the two-party considerations above.
} 
outcomes in 2002. First of all, 1998 was a major swing in the political landscape, away from the CDU towards the SPD and the Greens. Second, there was a major redistricting in 2002. While we drop observations that were difficult to match to older districts, there could still be a selection effect. In the 2005-2009 period, the governing ("grand") coalition consisted of the two major parties, CDU and SPD. When we drop the election in 1998 (that is, we drop those that run as incumbents in 2002), the results are unchanged and, if anything, stronger (table not included). When we include the 2005 election (and therefore, the 2009 outcomes), the results remain unchanged (not shown). ${ }^{28}$

Turning to the validity of our original design, we conduct a placebo test in which we set the threshold of the margin of victory to $-5 \%$ and $+5 \%$ respectively. In other words, if we set the threshold to $-5 \%$, we are comparing losers to losers, and if we set it to $+5 \%$ we are comparing winners to winners. The results for the period 1990-2005 using only the center-right party (CDU) are given in table 10 in the appendix. There are no stable effects of incumbency, especially for the specification using the interaction term. ${ }^{29}$

Further validation of our design comes from a histogram that shows the frequency of margins of victory. While not sufficient, such a frequency comparison gives an indication of whether close election occur with equal frequency on both sides of the threshold - an important aspect of whether the variation around the threshold is as good as random. The top panels of figure 7 show the distribution of margins of victory for the full sample (left) and zooming in on the range between $+/-10 \%$ (right). The lower panels show the frequencies by government participation in the subsequent period, zooming in on the sample $+/-20 \%$. In all four panels there are no noticable differences in the distribution to either side of the threshold.

A final test for the validity of the RDD is to check whether observations on either side of the threshold are balance in observable characteristics. Caughey and Sekhon (2011) suggest that the two variables are of specific interest: the predetermined vote share in the previous election and the past incumbency status. Figure 8 illustrates that we find no significant differences in the distributions of these variables. The upper two graphs show the binned averages in the mean, while the lower graphs focus on the second moment of the distribution. Overall, the tests of frequencies, placebo treatment, and predetermined variables indicate that our research design is valid.

\footnotetext{
${ }^{28}$ When we include the 2005-2009 period, we code the government interaction as SPD in government and $\mathrm{CDU}$ in government. Results are available from the authors upon request.

${ }^{29}$ The results are similar to those using the SPD, or using $+/-2 \%$ and $+/-10 \%$ as placebo thresholds (not shown).
} 


\section{Conclusion}

In this paper, we analyse the heterogeneity of incumbency effects for direct candidates in German federal elections. We find the same average effect for both parties that is previously identified in the literature. However, when we disaggregate the effects into government participation and opposition, we find noticeable differences between the two major parties: both parties have an incumbency effect only when the center-left party SPD is in government. This effect holds up in a wide range of specifications and even in state elections that are unrelated to federal elections.

As we show theoretically, it is impossible to identify an overall government participation effect because in a two party system, one incumbency effect is the mirror image of the other: if candidates of the governing party have an incumbency advantage, the opposition candidates have a likewise advantage because losers of one party reflect winners of the other. What we therefore identify is a heterogeneity in the government participation effect.

We also explore what might explain the heterogeneity in the incumbency effect. Based on additional evidence we argue that the increased pressure of the former communist party "The Left" on the center-left SPD after reunification may have induced the SPD to use its direct candidates more to its advantage when in government.

Beyond the main findings of the paper the results also expose a weakness in the current literature: average incumbency effects may not tell you much regarding the theoretical effects behind them. The observation we make that a positive effect for both parties is only present if the SPD is in government challenges the customary view that name recognition, presence in the media and pork-barrel spending matter for the incumbency advantage. Investigating the heterogeneity of these effects is therefore a promising avenue for future research. 


\section{References}

Abramowitz, A. I. (1975): "Name Familiarity, Reputation, and the Incumbency Effect in a Congressional Election," The Western Political Quarterly, 28(4), pp. 668-684.

Ade, F., ANd R. Freier (2011): "Incumbency, contamination and economic voting. Evidence from a quasi-experiment for Germany," Mimeo.

Ansolabehere, S., S. Hirano, J. M. Snyder, and M. Ueda (2001): "Party and Incumbency Cues in Voting: Are They Substitutes?," Quarterly Journal of Political Science, 1(2), 119-137.

Ansolabehere, S., E. C. Snowberg, and J. M. Snyder (2006): "Television and the Incumbency Advantage in U.S. Elections," Legislative Studies Quarterly, 31(4), 469-490.

Ansolabehere, S., And J. M. Snyder (2004): "Using Term Limits to Estimate Incumbency Advantages When Officeholders Retire Strategically," Legislative Office Quarterly, XXIX, 487-515.

Ansolabehere, S., J. M. Snyder, and C. Stewart (2000a): "Old Voters, New Voters, and the Personal Vote: Using Redistricting to Measure the Incumbency Advantage," American Journal of Political Science, 44(1), 17-34.

(2000b): "Old Voters, New Voters, and the Personal Vote: Using Redistricting to Measure the Incumbency Advantage," American Journal of Political Science, 44(1), $17-34$.

Bickers, K. N., And R. M. Stein (1996): "The Electoral Dynamics of the Federal Pork Barrel," American Journal of Political Science, 40(4), pp. 1300-1326.

Cain, B., J. Ferejohn, and M. Fiorina (1984): "The constituency service basis of the personal vote for U.S. representatives and British members of parliament," American Political Science Review, 78(1), 110-125.

Caughey, D. M., and J. S. Sekhon (2011): "Regression-Discontinuity Designs and Popular Elections: Implications of Pro-Incumbent Bias in Close U.S. House Races," Working Paper.

Cover, A. D. (1977): "One Good Term Deserves Another: The Advantage of Incumbency in Congressional Elections," American Journal of Political Science, 21(3), 523-541.

Cox, G. W., And J. N. Katz (1996): "Why Did the Incumbency Advantage in U.S. House Elections Grow?," American Journal of Political Science, 40(2), pp. 478-497. 
(2002): Elbrigde Gerry's Salamander: The Electoral Consequences of the Reappointment Revolution. Cambridge University Press.

Ferreira, F., and J. Gyourko (2009): "Do Political Parties Matter? Evidence from U.S. Cities," The Quarterly Journal of Economics, 124(1), 399-422.

FREIER, R. (2011): "Incumbency as the major advantage - The scopes and determinants of the electoral advantage for incumbent mayors," available as DIW working paper soon.

Freier, R., And C. Odendahl (2011): "Do Parties Matter? Estimating the effect of political representation in multi-party systems," Unpublished manuscript.

Gelman, A., And G. King (1990): "Estimating Incumbency Advantage without Bias," American Journal of Political Science, 34(4), 1142-1164.

Gordon, S. C., And G. A. Huber (2007): "The Effect of Electoral Competitiveness on Incumbent Behavior," Quarterly Journal of Political Science, 2(2), 107-138.

Grimmer, J., E. Hersh, B. Feinstein, and D. Carpenter (2011): "Are Close Elections Random?," Working Paper.

Hainmueller, J., And H. L. Kern (2005): "Incumbency Effects in German and British Elections: A Quasi-Experimental Approach," Working Paper.

(2008): "Incumbency as a source of spillover effects in mixed electoral systems: Evidence from a regression-discontinuity design," Electoral Studies, 27, 213-227.

Imbens, G., And T. Lemieux (2008): "Regression Discontinuity Designs: A Guide to Practice," Journal of Econometrics, 142, 615-635.

Jacobson, G. C. (1987): "The Marginals Never Vanished: Incumbency and Competition in Elections to the U.S. House of Representatives, 1952-82," American Journal of Political Science, 31(1), 126-141.

King, G., And A. Gelman (1991): "Systemic Consequences of Incumbency Advantage in U.S. House Elections," American Journal of Political Science, 35(1), 110-138.

Krehbiel, K., And J. R. Wright (1983): "The Incumbency Effect in Congressional Elections: A Test of Two Explanations," American Journal of Political Science, 27(1), $140-157$.

LEE, D. S. (2008): "Randomized experiments from non-random selection in U.S. House elections," Journal of Econometrics, 142, 675 - 697. 
Lee, D. S., E. Moretti, and M. Butler (2004): "Do Voters Affect or Elect Policies? Evidence from the U.S. House," Quarterly Journal of Economics, 119(3), 807-859.

LevitT, S. D., And C. D. Wolfram (1997): "Decomposing the Sources of Incumbency Advantage in the U. S. House," Legislative Studies Quarterly, 22(1), 45-60.

MAYHew, D. R. (1974): "Congressional Elections: The Case of the Vanishing Marginals," Polity, 6(3), 295-317.

Pettersson-Lidbom, P. (2008): "Do Parties Matter for Economic Outcomes? A Regression-Discontinuity Approach," Journal of the European Economic Association, 6(5), 1037-1056.

Snyder, J. M., O. Folke, and S. Hirano (2011): "A Simple Explanation for Bias at the 50-50 Threshold in RDD Studies Based on Close Elections1Are Close Elections Random?," Working Paper.

Snyder, J. M., and S. Hirano (2009): "Using Multi-Member Districts to Decompose the Incumbency Advantage," American Journal of Political Science, 53(2), 292-306.

Stein, R. M., And K. N. Bickers (1997): Perpetuating the pork barrel: Policy subsystems and American democracy. Cambridge University Press. 


\section{A Appendix}

\section{A.1 Graphical representation of the theoretical consideration}

A graphical representation of thetheoretical observation in section 2.1 may be helpful for an intuitive understanding. Let us assume that the incumbent can generate benefits for her district if, and only if, her party is in government. We further maintain the assumption of a pure two-party system. What we expect to see is the following (figure 4): if party $C$ is in government, those candidates of party $C$ that barely win (area II) compared to those that barely lost (area I) will experience an incumbency advantage at the next election because their party is in government. The winners in area II are driving the results so to speak.

Figure 4: Incumbency effect - from party $C$ 's standpoint

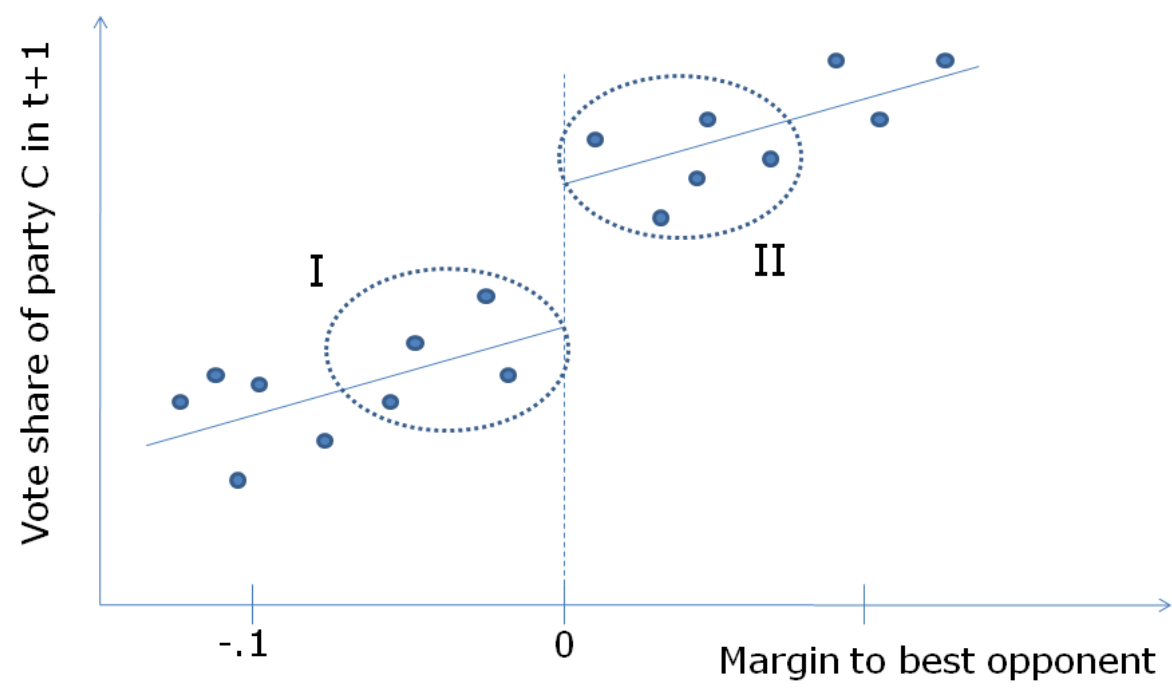

Somewhat surprisingly, we can use the same figure for party $C$ candidates if party $C$ is not in government. The losers in area I are now driving the results because their opponents are from party $S$ and are barely winners. Since party $S$ is in government, they receive an incumbency advantage in the next election compared to candidates of party $S$ that barely lost. The opponents of those that barely lost are from party $C$ and therefore we see an incumbency effect for those party $C$ winners even though the winners from party $S$ were, in fact, driving the results. The figure therefore shows that when both parties' incumbents benefit from being in government, the interaction term above will be zero. 
How would heterogeneity show in this figure? Assume once more that $\gamma^{C}$ is positive and $\delta^{C}$ is negative and both have the same size in absolute values. If party $S$ is in government, figure 4 still shows the effect of party $C$, captured by $\gamma^{C}$. Figure 5 then shows the effect when party $C$ is in government, captured by $\gamma^{C}$ plus the negative $\delta^{C}$. In this figure, the party $C$ winners in area II are the party $S$ losers when party $C$ is in government. Party $S$ incumbent winners in area I therefore experience no incumbency effect, captured by $\gamma^{S}$. Going back to figure 4 , however, we notice that party $S$ winners do have a large incumbency effect when they are in government, as the party $C$ losers in area I are the winners of party $S$, captured by $\gamma^{S}$ plus $\delta^{S}$.

Figure 5: Incumbency effect - again from party C's standpoint

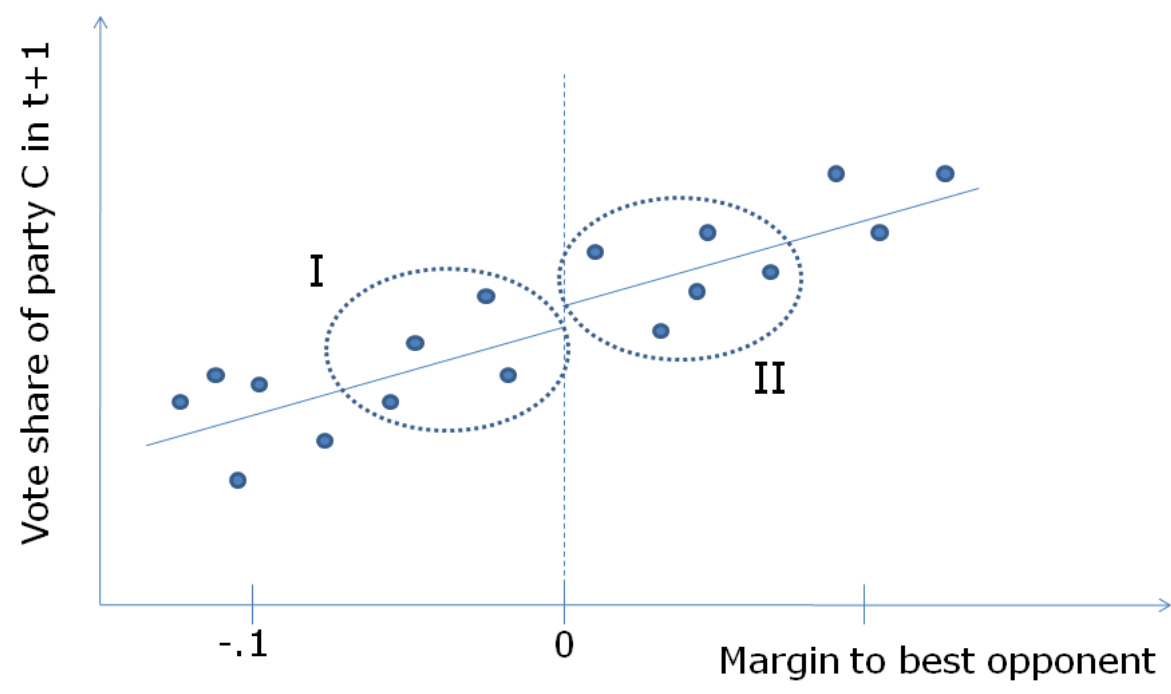

\section{A.2 Tables and Figures}


Figure 6: Vote share for the direct candidate of the Left party

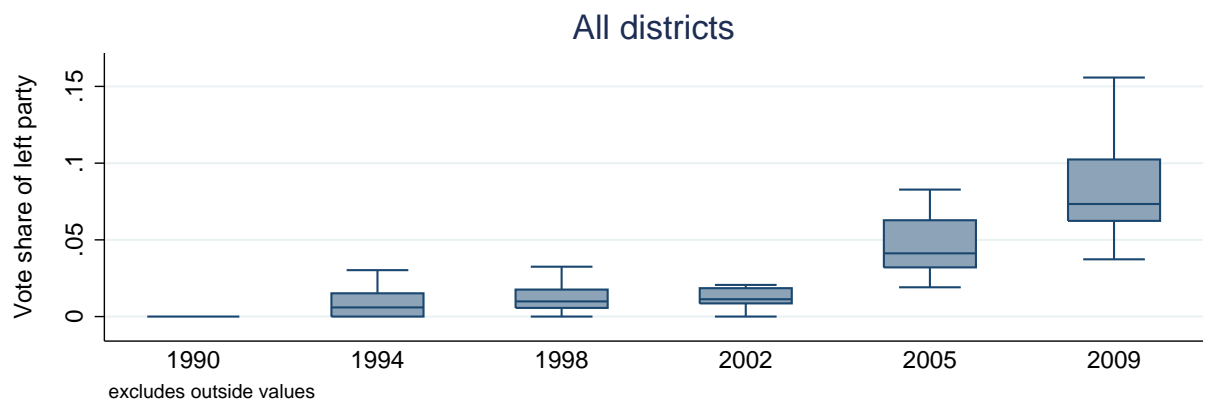

Districts in former East

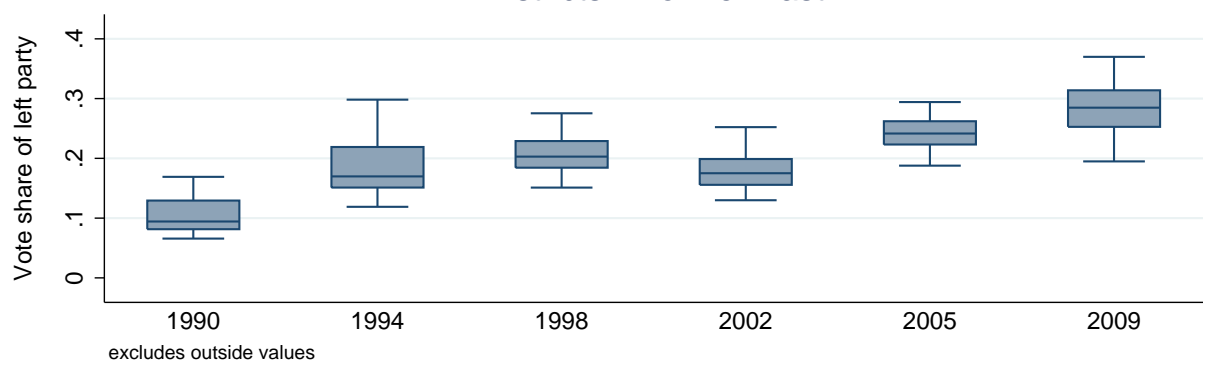

Notes: Source: Own calculations.

Figure 7: RDD validity - frequency histograms
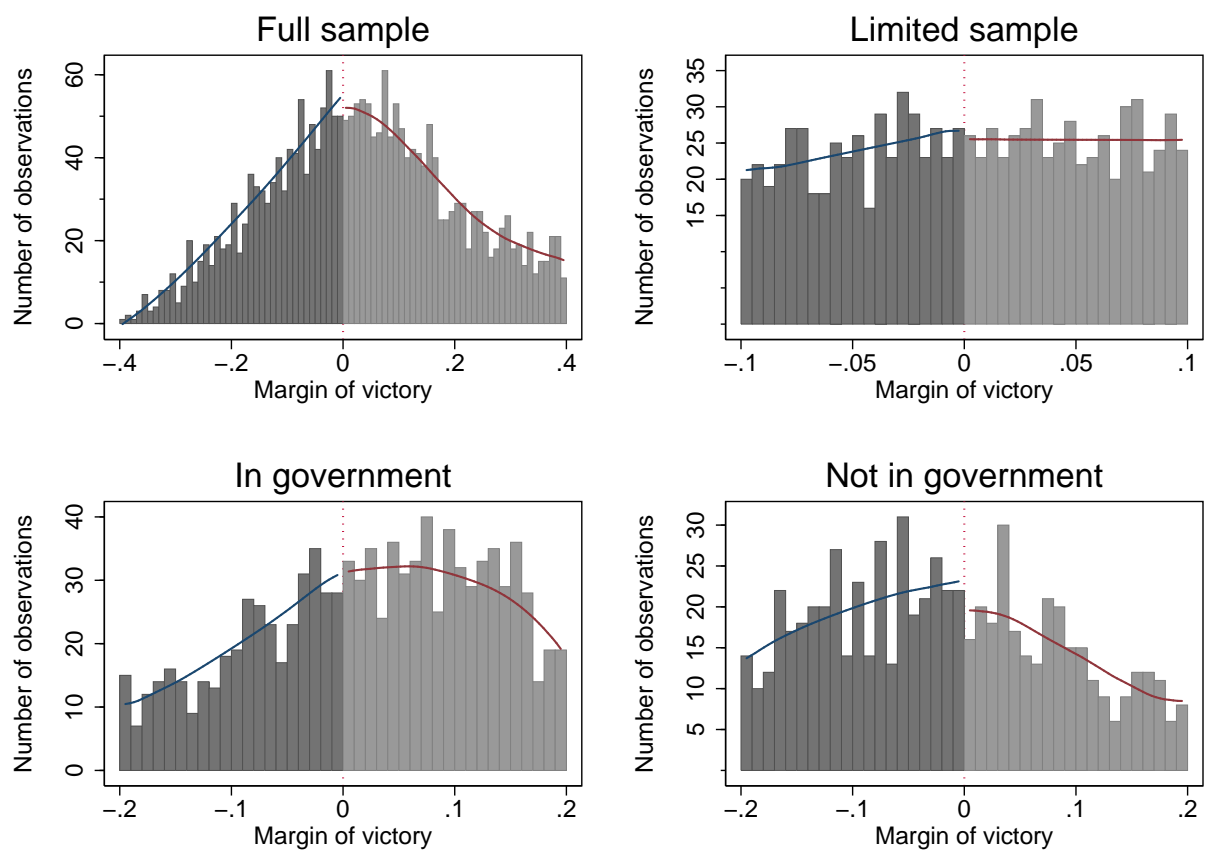

Notes: This figure presents the frequencies of observations in the data with respect to the margin of victory. Source: Own calculations. 
Table 2: Federal elections - party incumbency and government participation

\begin{tabular}{|c|c|c|c|c|c|c|}
\hline & \multicolumn{3}{|c|}{ Incumbency } & \multicolumn{3}{|c|}{ Gov. Participation } \\
\hline & $(1)$ & $(2)$ & $(3)$ & $(4)$ & $(5)$ & $(6)$ \\
\hline & \multicolumn{6}{|c|}{ Panel 1: Center-right party / CDU } \\
\hline $\begin{array}{l}\text { All elections 1976-2009 } \\
\text { Treatment }(\mathrm{d}) \\
\text { Interaction }(\mathrm{g} * \mathrm{~d})\end{array}$ & $\begin{array}{c}0.017^{* * *} \\
(0.004)\end{array}$ & $\begin{array}{l}0.010^{*} \\
(0.005)\end{array}$ & $\begin{array}{c}0.015^{* * *} \\
(0.004)\end{array}$ & $\begin{array}{c}0.029^{* * *} \\
(0.008) \\
-0.019^{* *} \\
(0.009)\end{array}$ & $\begin{array}{l}0.017^{*} \\
(0.010) \\
-0.011 \\
(0.011)\end{array}$ & $\begin{array}{c}0.021^{* * *} \\
(0.008) \\
-0.013 \\
(0.009)\end{array}$ \\
\hline $\begin{array}{l}\text { Period from 1976-1990 } \\
\text { Treatment }(\mathrm{d}) \\
\text { Interaction }(\mathrm{g} * \mathrm{~d})\end{array}$ & $\begin{array}{c}0.015^{* * *} \\
(0.005)\end{array}$ & $\begin{array}{c}0.005 \\
(0.007)\end{array}$ & $\begin{array}{l}0.010^{*} \\
(0.006)\end{array}$ & $\begin{array}{c}0.014^{*} \\
(0.008) \\
0.002 \\
(0.011)\end{array}$ & $\begin{array}{c}-0.002 \\
(0.008) \\
0.011 \\
(0.012)\end{array}$ & $\begin{array}{c}0.006 \\
(0.008) \\
0.006 \\
(0.011)\end{array}$ \\
\hline $\begin{array}{l}\text { Period from 1990-2005 } \\
\text { Treatment }(\mathrm{d}) \\
\text { Interaction }(\mathrm{g} * \mathrm{~d})\end{array}$ & $\begin{array}{c}0.020^{* * *} \\
(0.007)\end{array}$ & $\begin{array}{l}0.015^{*} \\
(0.008)\end{array}$ & $\begin{array}{c}0.020 * * * \\
(0.007)\end{array}$ & $\begin{array}{c}0.041^{* * *} \\
(0.015) \\
-0.036^{* *} \\
(0.016)\end{array}$ & $\begin{array}{c}0.032^{* *} \\
(0.015) \\
-0.030^{*} \\
(0.017)\end{array}$ & $\begin{array}{c}0.037^{* * *} \\
(0.012) \\
-0.030^{* *} \\
(0.014)\end{array}$ \\
\hline & & Pan & 2: Center- & party / SPI & & \\
\hline $\begin{array}{l}\text { All elections 1976-2009 } \\
\text { Treatment }(\mathrm{d}) \\
\text { Interaction }\left(\mathrm{g}^{*} \mathrm{~d}\right)\end{array}$ & $\begin{array}{c}0.023^{* * *} \\
(0.004)\end{array}$ & $\begin{array}{c}0.013^{* *} \\
(0.005)\end{array}$ & $\begin{array}{c}0.011^{* *} \\
(0.005)\end{array}$ & $\begin{array}{c}0.010 \\
(0.007) \\
0.025^{* * *} \\
(0.009)\end{array}$ & $\begin{array}{c}0.000 \\
(0.008) \\
0.024^{* *} \\
(0.011)\end{array}$ & $\begin{array}{c}0.002 \\
(0.008) \\
0.017^{*} \\
(0.010)\end{array}$ \\
\hline $\begin{array}{l}\text { Period from 1976-1990 } \\
\text { Treatment }(\mathrm{d}) \\
\text { Interaction }\left(\mathrm{g}^{*} \mathrm{~d}\right)\end{array}$ & $\begin{array}{c}0.022^{* * *} \\
(0.005)\end{array}$ & $\begin{array}{c}0.011 \\
(0.007)\end{array}$ & $\begin{array}{c}0.007 \\
(0.006)\end{array}$ & $\begin{array}{c}0.016^{*} \\
(0.008) \\
0.014 \\
(0.012)\end{array}$ & $\begin{array}{c}0.012 \\
(0.012) \\
-0.001 \\
(0.014)\end{array}$ & $\begin{array}{c}0.008 \\
(0.010) \\
-0.003 \\
(0.012)\end{array}$ \\
\hline $\begin{array}{l}\text { Period from 1990-2005 } \\
\text { Treatment }(\mathrm{d}) \\
\text { Interaction }(\mathrm{g} * \mathrm{~d})\end{array}$ & $\begin{array}{c}0.024^{* * *} \\
(0.007)\end{array}$ & $\begin{array}{l}0.015^{*} \\
(0.009)\end{array}$ & $\begin{array}{l}0.012^{*} \\
(0.007)\end{array}$ & $\begin{array}{c}0.009 \\
(0.008) \\
0.037^{* * *} \\
(0.013)\end{array}$ & $\begin{array}{c}-0.007 \\
(0.010) \\
0.051^{* * *} \\
(0.016)\end{array}$ & $\begin{array}{c}-0.006 \\
(0.010) \\
0.040 * * * \\
(0.014)\end{array}$ \\
\hline $\begin{array}{l}\text { N (Panel 1/ Panel 2) } \\
\text { Controlfunction } \\
\text { Sample } \\
\text { Year and state dummies }\end{array}$ & $\begin{array}{l}199 / 201 \\
\text { No } \\
2 \% \text { margin } \\
\text { Yes }\end{array}$ & $\begin{array}{c}514 / 524 \\
\text { linear } \\
5 \% \text { margin } \\
\text { Yes }\end{array}$ & $\begin{array}{l}2365 \\
4 \text { th order } \\
\quad \text { full } \\
\text { Yes }\end{array}$ & $\begin{array}{l}199 / 201 \\
\text { No } \\
2 \% \text { margin } \\
\quad \text { Yes }\end{array}$ & $\begin{array}{c}514 / 524 \\
\text { linear } \\
5 \% \text { margin } \\
\text { Yes }\end{array}$ & $\begin{array}{c}2365 \\
4 \text { th order } \\
\text { full } \\
\text { Yes }\end{array}$ \\
\hline
\end{tabular}

Notes: Significance levels: ${ }^{*} p<0.10,{ }^{* *} p<0.05,{ }^{* * *} p<0.01$. Standard errors in parentheses are robust. The dependent variable is the vote share of the respective party in $t$. The regressions in columns 1-3 indicate the pure party incumbency effect. Columns 4-6 also include the interaction between treatment (winning the district in $t-1$ ) and whether the party is in charge of government activity. Estimates in panel 1 are for the center-right party (CDU) and panel 2 show the results for the center-left party (SPD). Sample restrictions and control functions of the margin of victory are indicated below. Any polynomial control function of the degree indicated is specified to be flexible on both sides of the threshold. Source: Own calculations. 
Table 3: Federal elections - Probability of winning

\begin{tabular}{|c|c|c|c|c|c|c|}
\hline & \multicolumn{3}{|c|}{ Incumbency } & \multicolumn{3}{|c|}{ Gov. Participation } \\
\hline & $(1)$ & $(2)$ & $(3)$ & $(4)$ & $(5)$ & (6) \\
\hline & \multicolumn{6}{|c|}{ Panel 1: Center-right party } \\
\hline $\begin{array}{l}\text { Period 1976-1990 } \\
\text { Treatment }(\mathrm{d}) \\
\text { Interaction }\left(\mathrm{g}^{*} \mathrm{~d}\right)\end{array}$ & $\begin{array}{c}0.262^{* *} \\
(0.103)\end{array}$ & $\begin{array}{c}0.233^{*} \\
(0.125)\end{array}$ & $\begin{array}{c}0.316^{* * *} \\
(0.118)\end{array}$ & $\begin{array}{c}0.235^{*} \\
(0.118) \\
0.039 \\
(0.198)\end{array}$ & $\begin{array}{c}0.173 \\
(0.116) \\
0.076 \\
(0.217)\end{array}$ & $\begin{array}{c}0.292^{* * *} \\
(0.105) \\
-0.074 \\
(0.184)\end{array}$ \\
\hline $\begin{array}{l}\text { Period 1990-2005 } \\
\text { Treatment }(\mathrm{d}) \\
\text { Interaction }(\mathrm{g} * \mathrm{~d})\end{array}$ & $\begin{array}{c}0.241^{* *} \\
(0.095)\end{array}$ & $\begin{array}{c}0.226 * * \\
(0.098)\end{array}$ & $\begin{array}{c}0.161^{*} \\
(0.083)\end{array}$ & $\begin{array}{c}0.438^{* * *} \\
(0.164) \\
-0.342^{*} \\
(0.190)\end{array}$ & $\begin{array}{l}0.382^{* *} \\
(0.159) \\
-0.277 \\
(0.195)\end{array}$ & $\begin{array}{c}0.312^{* * *} \\
(0.120) \\
-0.316^{* *} \\
(0.157)\end{array}$ \\
\hline & & & anel 2: Cer & left party & & \\
\hline $\begin{array}{l}\text { Period 1976-1990 } \\
\text { Treatment }(\mathrm{d}) \\
\text { Interaction }\left(\mathrm{g}^{*} \mathrm{~d}\right)\end{array}$ & $\begin{array}{c}0.262^{* *} \\
(0.103)\end{array}$ & $\begin{array}{c}0.233^{*} \\
(0.125)\end{array}$ & $\begin{array}{c}0.316^{* * *} \\
(0.118)\end{array}$ & $\begin{array}{c}0.274^{*} \\
(0.146) \\
-0.039 \\
(0.198)\end{array}$ & $\begin{array}{c}0.249 \\
(0.176) \\
-0.076 \\
(0.217)\end{array}$ & $\begin{array}{c}0.218 \\
(0.148) \\
0.074 \\
(0.184)\end{array}$ \\
\hline $\begin{array}{l}\text { Period 1990-2005 } \\
\text { Treatment }(\mathrm{d}) \\
\text { Interaction }(\mathrm{g} * \mathrm{~d})\end{array}$ & $\begin{array}{c}0.235^{* *} \\
(0.092)\end{array}$ & $\begin{array}{c}0.215^{* *} \\
(0.098)\end{array}$ & $\begin{array}{c}0.193^{* *} \\
(0.083)\end{array}$ & $\begin{array}{c}0.091 \\
(0.100) \\
0.347^{*} \\
(0.188)\end{array}$ & $\begin{array}{c}0.064 \\
(0.112) \\
0.347^{*} \\
(0.194)\end{array}$ & $\begin{array}{c}0.012 \\
(0.100) \\
0.333^{* *} \\
(0.156)\end{array}$ \\
\hline $\begin{array}{l}\text { Controlfunction } \\
\text { Sample } \\
\text { Year and state dummies }\end{array}$ & $\begin{array}{l}\text { No } \\
2 \% \text { margin } \\
\text { Yes }\end{array}$ & $\begin{array}{l}\text { linear } \\
5 \% \text { margin } \\
\text { Yes }\end{array}$ & $\begin{array}{l}\text { 4th order } \\
\text { full } \\
\text { Yes }\end{array}$ & $\begin{array}{l}\text { No } \\
2 \% \text { margin } \\
\text { Yes }\end{array}$ & $\begin{array}{l}\text { linear } \\
5 \% \text { margin } \\
\text { Yes }\end{array}$ & $\begin{array}{c}\text { 4th order } \\
\text { full } \\
\text { Yes }\end{array}$ \\
\hline
\end{tabular}

Notes: Significance levels: ${ }^{*} p<0.10{ }^{* *} p<0.05,{ }^{* * *} p<0.01$. Standard errors in parentheses are robust. The dependent variable is the probability for the party of winning the district in $t$. The estimates are for the sub period 1990-2005. The regressions in columns 1-3 indicate the pure party incumbency effect. Columns 4-6 also include the interaction between treatment (winning the district in $t-1)$ and whether the party is in charge of government activity. Estimates in panel 1 are for the center-right conservative party and panel 2 show the results for the center-left social democrats. Sample restrictions and control functions of the margin of victory are indicated below. Any polynomial control function of the degree indicated is specified to be flexible on both sides of the threshold. Source: Own calculations. 
Table 4: Descriptives - state elections

\begin{tabular}{|c|c|c|c|c|c|c|c|}
\hline \multirow[t]{2}{*}{ State } & \multirow[t]{2}{*}{ Term } & \multirow[t]{2}{*}{ Obs. } & \multirow{2}{*}{$\begin{array}{c}\text { Head of } \\
\text { Government }\end{array}$} & \multicolumn{2}{|c|}{ Seats won } & \multicolumn{2}{|c|}{ Tight elections (CDU) } \\
\hline & & & & $\mathrm{CDU}$ & SPD & $2 \%$ margin & $5 \%$ margin \\
\hline Bav & '03-'08 & 91 & $\mathrm{CDU}$ & 91 & 0 & 0 & 1 \\
\hline Brand & '99-'04 & 44 & SPD & 2 & 37 & 4 & 10 \\
\hline Brand & '04-'09 & 44 & SPD & 4 & 17 & 4 & 8 \\
\hline Hesse & '03-'08 & 51 & $\mathrm{CDU}$ & 49 & 2 & 2 & 8 \\
\hline NRW & '05-'10 & 127 & $\mathrm{CDU}$ & 89 & 38 & 7 & 24 \\
\hline LS & '98-'03 & 100 & SPD & 16 & 84 & 7 & 17 \\
\hline LS & '03-'08 & 45 & $\mathrm{CDU}$ & 43 & 2 & 2 & 5 \\
\hline $\mathrm{RP}$ & '01-'06 & 51 & SPD & 21 & 30 & 6 & 20 \\
\hline SAAN & '94-'98 & 34 & $\mathrm{CDU}$ & 25 & 8 & 7 & 17 \\
\hline SAAN & '98-'02 & 34 & SPD & 2 & 32 & 2 & 4 \\
\hline SAAN & '02-'06 & 22 & $\mathrm{CDU}$ & 21 & 1 & 0 & 1 \\
\hline Thur & '99-'04 & 44 & $\mathrm{CDU}$ & 44 & 0 & 0 & 0 \\
\hline \multirow[t]{2}{*}{ Thur } & '04-'09 & 44 & $\mathrm{CDU}$ & 39 & 0 & 4 & 6 \\
\hline & & 731 & & 446 & 251 & 45 & 121 \\
\hline
\end{tabular}

Notes: Abbreviations: Bav - Bavaria, Brand - Brandenburg, NRW - North Rhine-Westphalia, LS - Lower Saxony, RP - Rhineland-Palatinate, SAAN- Saxony-Anhalt, Thur- Thuringia

Source: Own calculations based on the data provided by the state offices for statistical services. 
Table 5: Effects by region: incumbency in the former East and West

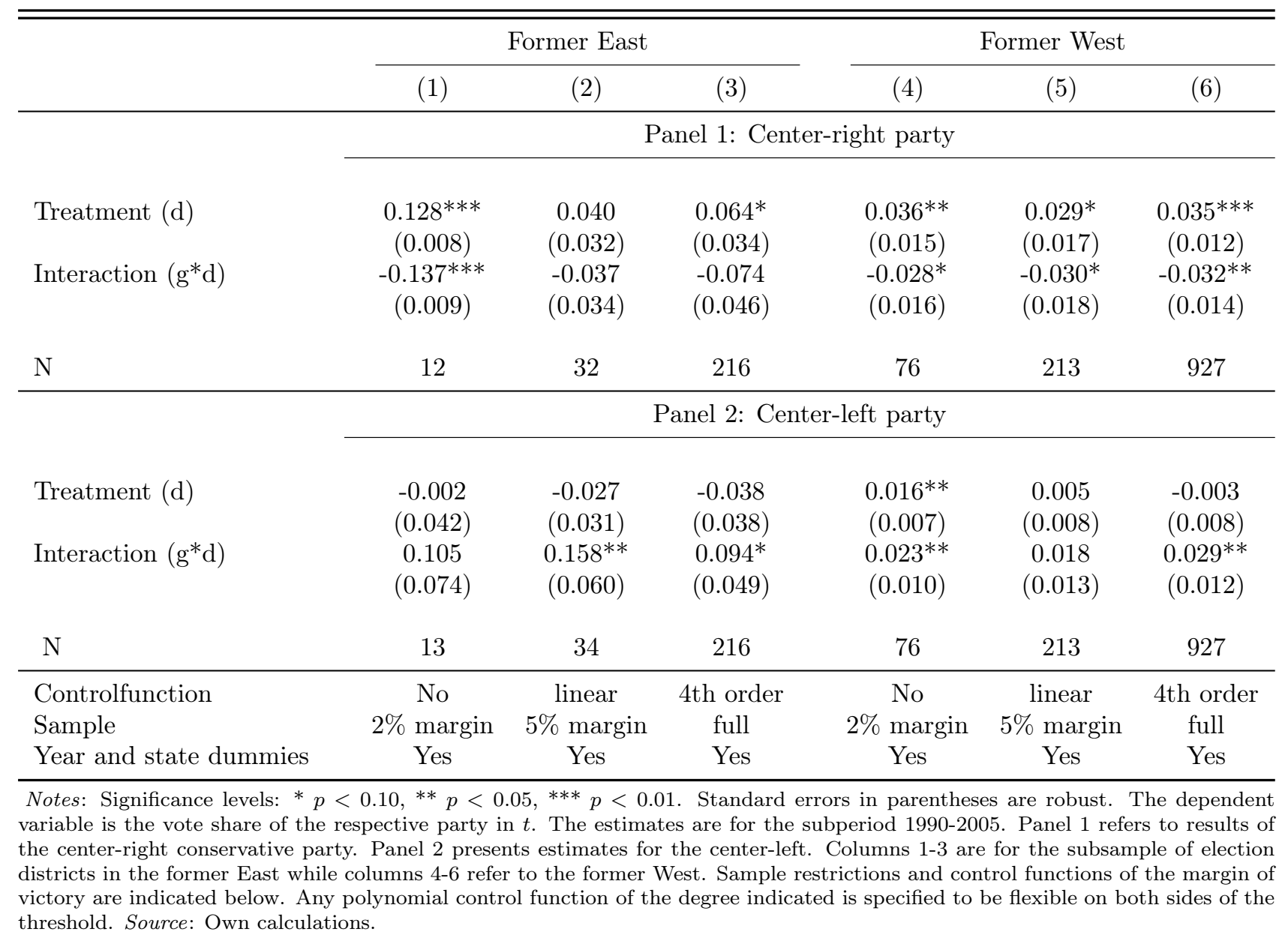


Table 6: Effect on the left party

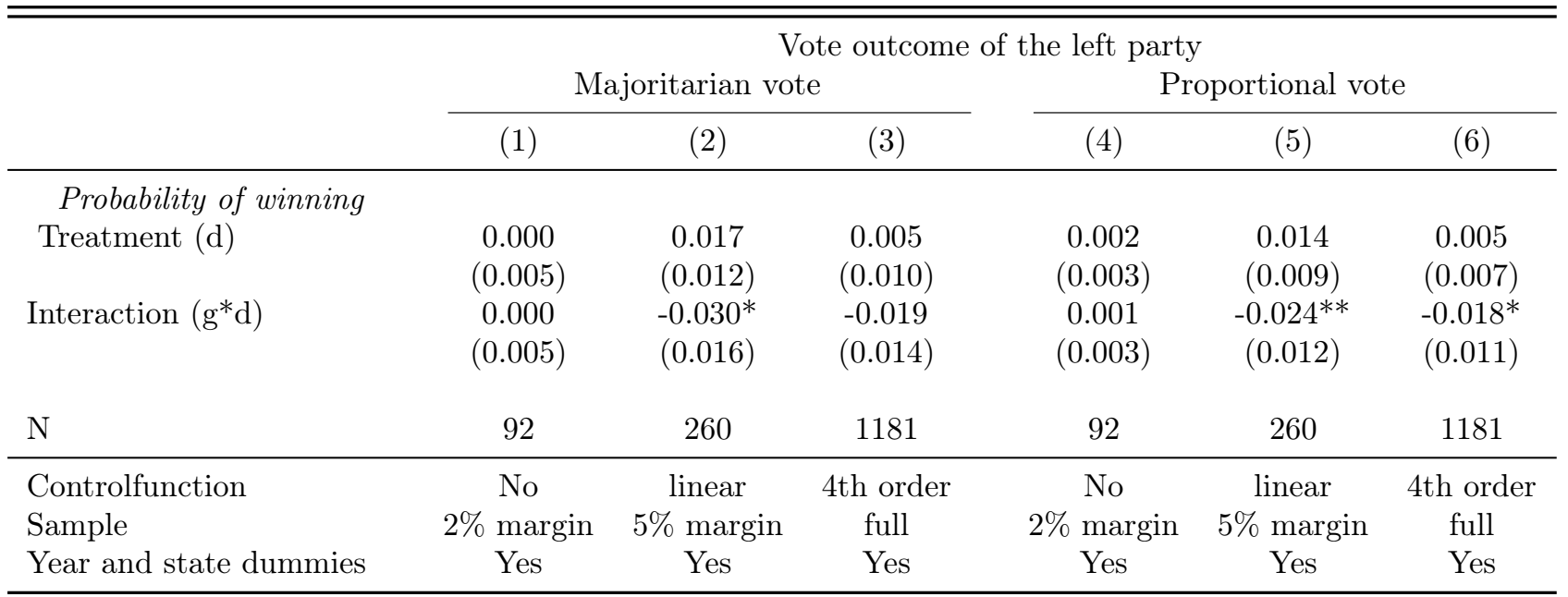

Notes: Significance levels: ${ }^{*} p<0.10,{ }^{* *} p<0.05,{ }^{* * *} p<0.01$. Standard errors in parentheses are robust. The dependent variable is the vote share of the left party in $t$ in the SPD design (margin of victory of the social democrats). The regressions in columns 1-3 indicate the effect on the majoritarian vote in different specification while columns 4-6 show the effects on the proportional vote. Treatment $d$ indicates that a SPD candidate won the district. The interaction $(g * d)$ means that the SPD incumbent has access to the government. Sample restictions and control functions of the margin of victory are indicated below. Any polynomial control function of the degree indicated is specified to be flexible on both sides of the threshold. Source: Own calculations. 
Table 7: Federal elections - party incumbency and government participation in the proportional vote

\begin{tabular}{|c|c|c|c|c|c|c|}
\hline & \multicolumn{3}{|c|}{ Incumbency } & \multicolumn{3}{|c|}{ Gov. Participation } \\
\hline & (1) & $(2)$ & $(3)$ & $(4)$ & $(5)$ & $(6)$ \\
\hline & \multicolumn{6}{|c|}{ Panel 1: Center-right party } \\
\hline $\begin{array}{l}\text { Treatment }(\mathrm{d}) \\
\text { Interaction }\left(\mathrm{g}^{*} \mathrm{~d}\right)\end{array}$ & $\begin{array}{c}0.018^{* *} \\
(0.007)\end{array}$ & $\begin{array}{c}0.010 \\
(0.009)\end{array}$ & $\begin{array}{c}0.018^{* *} \\
(0.007)\end{array}$ & $\begin{array}{c}0.039 * * \\
(0.015) \\
-0.037^{* *} \\
(0.016)\end{array}$ & $\begin{array}{c}0.028 \\
(0.018) \\
-0.032^{*} \\
(0.019)\end{array}$ & $\begin{array}{c}0.034^{* * *} \\
(0.012) \\
-0.028^{* *} \\
(0.014)\end{array}$ \\
\hline \multirow[t]{2}{*}{$\mathrm{N}$} & 91 & 252 & 1181 & 91 & 252 & 1181 \\
\hline & \multicolumn{6}{|c|}{ Panel 2: Center-left party } \\
\hline $\begin{array}{l}\text { Treatment }(\mathrm{d}) \\
\text { Interaction }\left(\mathrm{g}^{*} \mathrm{~d}\right)\end{array}$ & $\begin{array}{c}0.016 * * \\
(0.006)\end{array}$ & $\begin{array}{l}0.012^{*} \\
(0.008)\end{array}$ & $\begin{array}{c}0.005 \\
(0.007)\end{array}$ & $\begin{array}{c}0.009 \\
(0.009) \\
0.016 \\
(0.014)\end{array}$ & $\begin{array}{c}0.004 \\
(0.010) \\
0.018 \\
(0.015)\end{array}$ & $\begin{array}{c}0.000 \\
(0.010) \\
0.014 \\
(0.014)\end{array}$ \\
\hline $\mathrm{N}$ & 92 & 260 & 1181 & 92 & 260 & 1181 \\
\hline $\begin{array}{l}\text { Controlfunction } \\
\text { Sample } \\
\text { Year and state dummies }\end{array}$ & $\begin{array}{ll}\text { No } \\
2 \% \\
\text { margin } \\
\text { Yes }\end{array}$ & $\begin{array}{l}\text { linear } \\
5 \% \text { margin } \\
\text { Yes }\end{array}$ & $\begin{array}{l}\text { 4th order } \\
\text { full } \\
\text { Yes }\end{array}$ & $2 \%$ margin & $\begin{array}{l}\text { linear } \\
5 \% \text { margin } \\
\text { Yes }\end{array}$ & $\begin{array}{l}\text { 4th order } \\
\text { full } \\
\text { Yes }\end{array}$ \\
\hline
\end{tabular}

Notes: Significance levels: ${ }^{*} p<0.10,{ }^{* *} p<0.05$, *** $p<0.01$. Standard errors in parentheses are robust. The dependent variable is the vote share of the respective party in the proportional vote (Zweitstimme) in $t$. The estimates are for the sub period 1990-2005. The regressions in columns 1-3 indicate the pure party incumbency effect. Columns 4-6 also include the interaction between treatment (winning the district in $t-1$ ) and whether the party is in charge of government activity. Estimates in panel 1 are for the center-right conservative party and panel 2 show the results for the center-left social democrats. Sample restrictions and control functions of the margin of victory are indicated below. Any polynomial control function of the degree indicated is specified to be flexible on both sides of the threshold. Source: Own calculations. 
Table 8: State elections - party incumbency and government participation

\begin{tabular}{|c|c|c|c|c|c|c|}
\hline & \multicolumn{3}{|c|}{ Incumbency } & \multicolumn{3}{|c|}{ Gov. Participation } \\
\hline & (1) & $(2)$ & (3) & $(4)$ & $(5)$ & $(6)$ \\
\hline & \multicolumn{6}{|c|}{ Panel 1: Center-right party } \\
\hline Treatment (d) & $\begin{array}{c}0.026^{* *} \\
(0.012)\end{array}$ & $\begin{array}{l}0.036^{*} \\
(0.020)\end{array}$ & $\begin{array}{c}0.025^{* *} \\
(0.013)\end{array}$ & $\begin{array}{c}0.052^{* * *} \\
(0.017)\end{array}$ & $\begin{array}{c}0.041^{* *} \\
(0.020)\end{array}$ & $\begin{array}{c}0.057^{* * *} \\
(0.019)\end{array}$ \\
\hline Interaction $(\mathrm{g} * \mathrm{~d})$ & & & & $\begin{array}{c}-0.053^{* *} \\
(0.020)\end{array}$ & $\begin{array}{c}-0.065^{* *} \\
(0.026)\end{array}$ & $\begin{array}{c}-0.065^{* *} \\
(0.025)\end{array}$ \\
\hline \multirow[t]{2}{*}{$\mathrm{N}$} & 45 & 121 & 731 & 45 & 121 & 731 \\
\hline & \multicolumn{6}{|c|}{ Panel 2: Center-left party } \\
\hline Treatment (d) & $\begin{array}{c}0.008 \\
(0.013)\end{array}$ & $\begin{array}{l}-0.005 \\
(0.016)\end{array}$ & $\begin{array}{c}0.007 \\
(0.013)\end{array}$ & $\begin{array}{l}-0.023 \\
(0.029)\end{array}$ & $\begin{array}{l}-0.051 \\
(0.036)\end{array}$ & $\begin{array}{l}-0.045 \\
(0.037)\end{array}$ \\
\hline Interaction $(\mathrm{g} * \mathrm{~d})$ & & & & $\begin{array}{c}0.047 \\
(0.031)\end{array}$ & $\begin{array}{l}0.072^{*} \\
(0.039)\end{array}$ & $\begin{array}{c}0.084^{* *} \\
(0.040)\end{array}$ \\
\hline $\mathrm{N}$ & 51 & 129 & 731 & 51 & 129 & 731 \\
\hline Controlfunction & No & linear & 4th order & No & linear & 4th order \\
\hline Sample & $2 \%$ margin & $5 \%$ margin & full & $2 \%$ margin & $5 \%$ margin & full \\
\hline Election dummies & Yes & Yes & Yes & Yes & Yes & Yes \\
\hline
\end{tabular}

Notes: 'Margin' in this table means the difference in percentage points between the winner and the next best opponent. For example, in the case of only two candidates a margin of 5 percent means that the winner may have gotten at most 52.5 percent while the other got 47.5 percent. Source: Own calculations based on the data provided by the state offices for statistical services. 
Table 9: Winners of close races by governmental lead

\begin{tabular}{|c|c|c|c|c|c|c|}
\hline & \multicolumn{2}{|c|}{ Lead CDU } & \multicolumn{2}{|c|}{ Lead SPD } & \multicolumn{2}{|c|}{ Difference } \\
\hline & SPD & $\mathrm{CDU}$ & SPD & $\mathrm{CDU}$ & SPD & $\mathrm{CDU}$ \\
\hline \multicolumn{7}{|l|}{ 1. Gender } \\
\hline Share of women & 0.26 & 0.04 & 0.23 & 0.06 & $\begin{array}{c}0.03 \\
(0.76)\end{array}$ & $\begin{array}{l}-0.02 \\
(0.74)\end{array}$ \\
\hline \multicolumn{7}{|l|}{ 2. Local Ties } \\
\hline Share born in district & 0.58 & 0.48 & 0.41 & 0.61 & $\begin{array}{c}0.17 \\
(0.11)\end{array}$ & $\begin{array}{l}-0.13 \\
(0.23)\end{array}$ \\
\hline \multicolumn{7}{|l|}{ 3. Qualification } \\
\hline Share with university degree & 0.72 & 0.68 & 0.68 & 0.75 & $\begin{array}{c}0.04 \\
(0.69)\end{array}$ & $\begin{array}{l}-0.07 \\
(0.49)\end{array}$ \\
\hline Share with important positions & 0.30 & 0.26 & 0.30 & 0.22 & $\begin{array}{c}0.00 \\
(0.94)\end{array}$ & $\begin{array}{c}0.04 \\
(0.69)\end{array}$ \\
\hline \multicolumn{7}{|l|}{ 4. Seniority } \\
\hline \# of periods in parliament & 2.58 & 3.30 & 2.61 & 2.69 & $\begin{array}{l}-0.03 \\
(0.93)\end{array}$ & $\begin{array}{c}0.61 \\
(0.14)\end{array}$ \\
\hline \# of years in parliament & 5.74 & 8.36 & 6.36 & 6.53 & $\begin{array}{c}-.62 \\
(0.64)\end{array}$ & $\begin{array}{c}1.83 \\
(0.24)\end{array}$ \\
\hline \# of years in the party & 21.30 & 24.57 & 23.22 & 23.96 & $\begin{array}{l}-1.92 \\
(0.34)\end{array}$ & $\begin{array}{c}0.61 \\
(0.81)\end{array}$ \\
\hline$\#$ of Obs & 43 & 50 & 44 & 36 & & \\
\hline
\end{tabular}

Notes: The data covers the full sample from 1976 to 2009. Standard errors for the difference are reported in parenthesis. Significance levels: ${ }^{*} p<0.10,{ }^{* *} p<0.05,{ }^{* * *} p<0.01$. 
Table 10: Placebo tests - majoritarian vote of center-right party in federal elections

\begin{tabular}{|c|c|c|c|c|c|c|}
\hline & \multicolumn{6}{|c|}{$\begin{array}{l}\text { Dep. Variable: vote share in majoritarian vote for center-right party } \\
\text { Incumbency } \\
\text { Gov. Participation }\end{array}$} \\
\hline & (1) & $(2)$ & $(3)$ & $(4)$ & $(5)$ & $(6)$ \\
\hline & \multicolumn{6}{|c|}{ Panel 1: Minus 5 percent } \\
\hline $\begin{array}{l}\text { Treatment }(d) \\
\text { Interaction }(g * d)\end{array}$ & $\begin{array}{c}0.008 \\
(0.005)\end{array}$ & $\begin{array}{l}0.000 \\
(0.007)\end{array}$ & $\begin{array}{l}-0.002 \\
(0.006)\end{array}$ & $\begin{array}{c}0.013 \\
(0.010) \\
-0.008 \\
(0.011)\end{array}$ & $\begin{array}{c}0.009 \\
(0.013) \\
-0.015 \\
(0.014)\end{array}$ & $\begin{array}{c}0.000 \\
(0.011) \\
-0.004 \\
(0.013)\end{array}$ \\
\hline \multirow[t]{2}{*}{$\mathrm{N}$} & 112 & 256 & 1181 & 112 & 256 & 1181 \\
\hline & \multicolumn{6}{|c|}{ Panel 2: Plus 5 percent } \\
\hline $\begin{array}{l}\text { Treatment }(d) \\
\text { Interaction }(g * d)\end{array}$ & $\begin{array}{c}0.002 \\
(0.006)\end{array}$ & $\begin{array}{c}-0.011^{*} \\
(0.007)\end{array}$ & $\begin{array}{r}-0.012^{*} \\
(0.007)\end{array}$ & $\begin{array}{c}0.004 \\
(0.009) \\
-0.004 \\
(0.011)\end{array}$ & $\begin{array}{c}-0.010 \\
(0.009) \\
-0.001 \\
(0.013)\end{array}$ & $\begin{array}{c}-0.009 \\
(0.009) \\
-0.003 \\
(0.015)\end{array}$ \\
\hline $\mathrm{N}$ & 98 & 237 & 1181 & 98 & 237 & 1181 \\
\hline $\begin{array}{l}\text { Controlfunction } \\
\text { Sample } \\
\text { Year and state dummies }\end{array}$ & $\begin{array}{l}\text { No } \\
2 \% \text { margin } \\
\text { Yes }\end{array}$ & $\begin{array}{l}\text { linear } \\
5 \% \text { margin } \\
\text { Yes }\end{array}$ & $\begin{array}{l}\text { 4th order } \\
\text { full } \\
\text { Yes }\end{array}$ & $\begin{array}{l}\text { No } \\
2 \% \text { margin } \\
\text { Yes }\end{array}$ & $\begin{array}{l}\text { linear } \\
5 \% \text { margin } \\
\text { Yes }\end{array}$ & $\begin{array}{l}\text { 4th order } \\
\text { full } \\
\text { Yes }\end{array}$ \\
\hline
\end{tabular}

Notes: Significance levels: ${ }^{*} p<0.10,{ }^{* *} p<0.05,{ }^{* * *} p<0.01$. Standard errors in parentheses are robust. The dependent variable is the vote share of the respective party in $t$. Panel 1 refers to results of the placebo test in which we simulate that a party obtained the district incumbency status also if it lost the district race with at most 5 percentage points. Panel 2 presents estimates for the reverse placebo test in which a party needed more than 5 percentage points winning margin to gain the incumbency status. The regressions in columns 1-3 indicate the pure party incumbency effect. Columns 4-6 also include the interaction between treatment (winning the district in $t-1$ ) and whether the party is in charge of government activity. Sample restrictions and control functions of the margin of victory are indicated below. Any polynomial control function of the degree indicated is specified to be flexible on both sides of the threshold. Source: Own calculations. 
Figure 8: RDD validity - predetermined variables
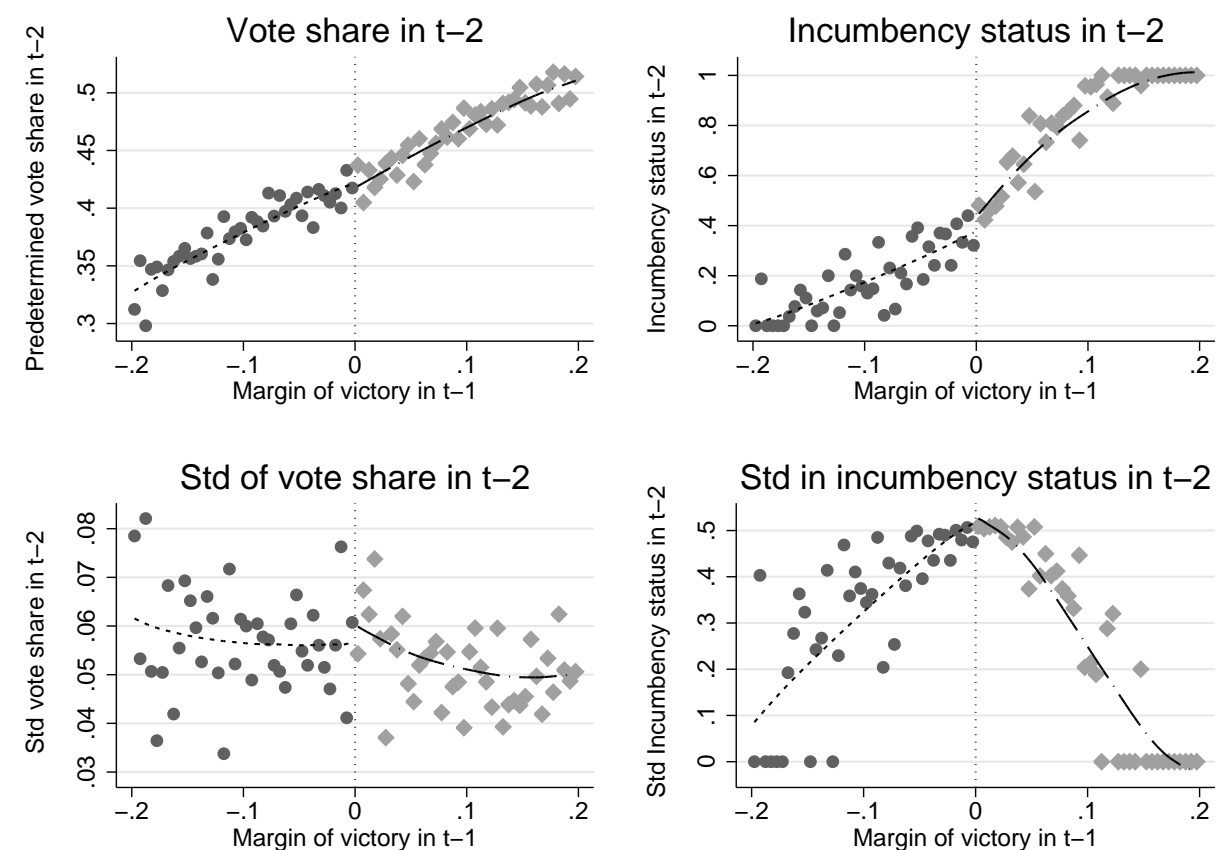

Notes: The figures show the relationship between the margin of victory for the CDU in t- 1 and two predetermined variables: vote share and incumbency status both in t-2. For clarity the data have been grouped in bins, each bin representing an interval of 0.5 percent in the margin of victory. We display only the observations within a margin of victory of 0.2 to draw the focus on the decisive threshold. The upper two graphs show the first moments, while second moments of the variables are displayed in the lower graphs. The lines fitted onto the data is based on a local kernel regression using endogenous Epanechnikov weights. We also estimate the effects on the predetermined variables in regressions similar to the ones presented in table 2 and we found no significant differences in the predetermined variables. Source: Own calculations. 